Int. J. Dev. Biol. 53: 1609-1622 (2009)

doi: $10.1387 / \mathrm{ijdb} .072296 \mathrm{em}$

\title{
The role of ion fluxes in polarized cell growth and morphogenesis: the pollen tube as an experimental paradigm
}

\author{
ERWAN MICHARD ${ }^{1}$, FILIPA ALVES ${ }^{1}$ and JOSÉ A. FEIJÓ ${ }^{1,2, *}$ \\ ${ }^{1}$ Centro de Biologia do Desenvolvimento, Instituto Gulbenkian de Ciência, Oeiras and \\ 2 Universidade de Lisboa, Faculdade de Ciências, Dept. Biologia Vegetal, Campo Grande, Lisboa, Portugal
}

\begin{abstract}
In order to cope with reproduction in a dry environment without any sort of motility, plants have developed a very specialized and unique sexual system. Of special notice, the two sperm cells that will perform the double fertilization typical of higher plants are carried by one of the fastest growing cells in nature, the pollen tube. This tube develops from the vegetative cell of the pollen grain upon germination on the female tissues. While it cannot be considered as a canonical excitable cell, pollen tubes depend for most of their fundamental functional features on a close regulation of ion dynamics, namely in terms of polarization of extracellular fluxes and formation of standing cytosolic free ion gradients, namely of calcium $\left(\mathrm{Ca}^{2+}\right)$ and protons $\left(\mathrm{H}^{+}\right)$. In turn, these imply that plasma membrane transporters are polarized, or polarly regulated, and that internal signaling cascades transduce this spatial information into the basic features of growth and morphogenesis needed for pollen tubes to target correctly the ovules and discharge the sperm cells. Because of the singularity of this organization, and the ease with which pollen tubes can be experimentally handled, recent years have witnessed an accumulation of data at many levels, from basic biophysical and cell biology characterization, to gene assignment and transcriptomic description of pollen development. In this review we aim to organize this information in terms of the basic biophysical features of membrane function and integrate it into conceptual testable hypotheses on how the dynamics of ion regulation may underlie fundamental properties of cell development.
\end{abstract}

KEY WORDS: Plant development, pollen, ion channel, proton pump, cell polarization

\section{Introduction}

Evolution has shaped higher plants with an extraordinarily specialized and differentiated sexual reproduction system that allowed the adaptation to sessile habits and dry environments, in turn making it possible for plants to successfully colonize all habitats. Among these evolutionary singularities, stems the capacity to transport and deliver non-motile male sperm from great distances apart. The system basically works through the development of the pollen grain, the male gametophyte of plants. This organ is released to the atmosphere in a highly dehydrated state, surrounded by a "bullet-proof" external wall. These features make pollen fit to endure large trips through a possibly aggressive atmosphere, until landing on the female sexual organ, the pistil. If the cross is compatible and viable, re-hydration of pollen takes place and germination occurs, giving rise to the pollen tube (Boavida et al., 2005a,b).
The pollen tube is a highly specialized cell that results from the germination of pollen and the outgrowth of its vegetative cell after pollination. This fast growing cytoplasmic extension (or tube) serves to transport the sperm cells contained within the pollen grain from the external surface of the female reproductive organs (the stigma) down to the core of the ovary, and eventually deliver them to the ovule for the typical double fertilization of plants. This implies a long and very rapid, divisionless, growth of the pollen tube (reviewed in Boavida et al., 2005a,b). In fact these cells lineup within the ones that grow faster in nature, with linear growth rates up to $4 \mu \mathrm{m} \cdot \mathrm{sec}^{-1}$ (e.g. in species like Tradescantia or Hemerocallis) and extension lengths up to $40-50 \mathrm{~cm}$ (e.g. maize). Having in mind that a typical pollen grain is not much more than

Abbreviations used in this paper: Em, electrical membrane potential; Nt AHA, nicotiana $\mathrm{H}^{+}$ATPase; PM, plasma membrane.

*Address correspondence to: José A. Feijó. Centro de Biologia do Desenvolvimento, Instituto Gulbenkian de Ciência, PT-2780-156 Oeiras, Portugal.
Fax: +351-21-440-7970. e-mail: jfeijo@fc.ul.pt

Final author-corrected PDF published online: 24th April 2008.

ISSN: Online 1696-3547, Print 0214-6282

() 2009 UBC Press

Printed in Spain 
a $100 \mu \mathrm{m}$ spheroid organ, this may imply a multiplication of volume of several orders of magnitude, sometimes within a few hours.

To sustain this amount of growth, pollen tubes must have by default an efficient ion transport system at the plasma membrane (PM). Indeed, the volume increase of the tube induced by its extension implies water and solute influx into the cell and accumulation into its expanding vacuole. On the other hand, the growing tube accumulates new charged organic material, which implies the corresponding entry of specific ions to compensate the charge balance of the newly acquired or synthesized molecules.

More interestingly, in addition to playing a role in the growth itself, ion transporters and other interacting proteins make certain ions pivotal components of the cell signaling network by themselves. Overwhelming amounts of literature prove that to be the case for calcium $\left(\mathrm{Ca}^{2+}\right)$ but significant evidence shows that to be the case for others as well, most notably protons $\left(\mathrm{H}^{+}\right)$. These transduction pathways are presumably involved in the self-organization of pollen after re-hydration, and therefore are expected to have roles in the control of polarized establishment of growth that eventually leads to the differentiation and sustained growth of the pollen tube (Feijó et al., 1995; 2001; 2004; Boavida et al., 2005b).

Pollen tubes also share many commonalities with a number of other apical growing cells, namely root hairs, fungal hyphae or in certain cases neurite outgrowths (see e.g. Palanivelu and Preuss, 2000). Of special relevance for comparative purposes, root-hairs play a central role in the high affinity uptake of nutrients by the root. It becomes therefore natural that these two cells have been elected as prominent plant cell models for the study of polarized growth. In addition to common cellular features at the level of shape and cytoplasm polarization, root hairs also developed unique ion dynamics systems for signaling (see e.g. Cárdenas et al., 2000).

Many of the central issues arising from the studies of pollen tubes and root hairs have been defined around cell shape and sub-cellular polarization. The study of ion transporter systems is a key point to address both of these questions, because to date all fluxes, intracellular free concentration, and sub-cellular localization of transporters were shown to be conspicuously polarized. Substantial evidence also showed that ion transporters are necessary for cell organization, presumably through the control of polarization via signaling networks. Last but not least, ion transporters play important roles in the respective organ physiology, namely allowing a fast growth and rapid uptake of ions, presumably underlying an efficient high affinity uptake of molecules.

Recently, high-throughput genetic data was obtained in the pollen grain, with the description of the nearly-full transcriptome of Arabidopsispollen (Becker etal., 2003; Honys and Twell, 2003, 2004; Pina et al., 2005). In parallel, substantial efforts are also being made on the pollen proteome (e.g. Noir et al., 2005), opening new possibilities to establish the pollen tube as a model system (see review by Becker and Feijó, 2007). In short, the wealth of molecular data published in the recent years allowed a better understanding of the pollen tube ion transport system and set the background for specific hypotheses to be tested in terms of functional genetics.

In this review, we will describe the molecular nature and the role of ion transport systems in the pollen tube physiology in the light of these new results. Furthermore, we will discuss the implications and shortcuts of current models for the role of the ion transport polarization in nutrient uptake efficiency.

\section{Pollen tubes: an electrically exciting cell!}

Ever since the pioneer studies in the group of Lionel Jaffe established cells as generators of physically well defined electrical currents, pollen tubes are known to behave as electrical dipoles, with outward (positive charges) currents arising from the grain, and inward currents leaking the apical parts of the tube (Fig. 1A; Weisenseel et al., 1975; Weisenseel and Jaffe, 1976). Most of this data was acquired with a then newly developed method, the vibrating-probe, which consisted of a metal electrode measuring voltage differences between two adjacent points, thus inferring the total electric current from the difference between the sum of charge activity in the two points. While establishing a whole new field in terms of physiological development, this original version of the vibrating probe was also posed with technical limitations that hindered some of the biologically relevant properties inherent to these currents. Most notably, these probes effectively agitated the medium at high frequencies, thus destroying small or slow moving ion gradients generated around cells. Moreover, the determination of the specific ion species underlying the current was not possible. Some approaches were attempted with substitution/ addition experiments, but a combination of technical issues made it hard to interpret the data in terms of the specific ions that carry those currents.

A few groups concurred then to develop ion-specific vibrating probes, today known under different acronyms, but basically all exploring the same sort of biophysical properties of artificial ionophore cocktails (e.g. SIET, SERIS, MIFE, see Kunkel et al., 2006).

Application of these methods to pollen tubes soon allowed the drawing of a map of the main inorganic ion fluxes they drive. Amazingly, most ion fluxes seem to follow what could be characterized as a "short-circuit" loop across the pollen tube (see Fig. 1 $B, C)$. In sheer thermodynamic terms, this scheme implies an obvious waste of energy, and therefore a justification for these "short-circuits" must be sough in terms of local "energization" for tighter, spatially restricted control.

$\mathrm{Ca}^{2+}$ and $\mathrm{H}^{+}$have been reported to enter massively the tip (Feijó etal., 1999; Feijó, 1999; Messerli etal., 1999; Robinson and Messerli, 2002). Protons then leak out mostly through the PM of the tube and the grain (Feijó et al., 1999; Feijó, 1999, Certal et al., 2008). Anions, most notably chloride $\left(\mathrm{Cl}^{-}\right)$have been shown to have a reverse direction, entering the tube / grain and leaving massively through the tip (Zonia et al., 2002). This first work was performed using a low $\mathrm{pH}$ buffer concentration (MES in the $\mu \mathrm{M}$ range), a condition necessary to optimize signal/ noise $(\mathrm{S} / \mathrm{N})$ ratio when using artificial ion probes. A different set of conditions was used by Messerli et al. (2004), and under low buffer concentrations the authors obtained the same results as Zonia et al. (2002). Messerli et al. (2004) however attempted to create a number of other experimental conditions to dismiss a role for $\mathrm{Cl}^{-}$in pollen tube, but to our eyes, these authors not only failed to reproduce our exact measuring conditions, as they failed to build a sufficiently compelling case to rule out a role for $\mathrm{Cl}^{-}$in pollen tube regulation. Of special notice, they chose to ignore a number of other pieces of evidence using pharmacology, specific inositol 
molecules effects and hydrodynamic experiments, all pointing out to a role for chloride on water transport control. Future experiments, namely coupling biophysical with molecular data, will surely disentangle the doubts created by the study of Messerli et al. (2004), aimed at specifically dismissing the data by Zonia et al. (2002) but proposing no other alternative model for anion transport in pollen tubes.

Curiously enough, the same group described strong influxes of potassium $\left(\mathrm{K}^{+}\right)$at the tip, but mentioning no other coupled fluxes

Fig. 1. Current model for ion fluxes around the pollen tube: an active transport system at the tube, and a passive transport system at the tip. (A) Electrical model for the lily (Lilium Iongiflorum) pollen tube, deduced from the extracellular electric currents, as determined by the original voltage-vibrating probe. A net current of positive charges enters the tip, leaking by the tube and grain, is hypothesized to transverse the cytoplasm with a net intensity of about $1 \mathrm{pAmp}$ (adapted from Weisenseel et al., 1975). (B) Inorganic ion fluxes around the pollen tube of tobacco (Nicotiana tabacum) as recorded using the ion-specific vibrating probe technique. $\mathrm{Ca}^{2+}$ and $\mathrm{H}^{+}$leave the pollen tube, via ATPases and enter the tip, via channels for $\mathrm{Ca}^{2+}$, and non-identified transporters for $\mathrm{H}^{+}$. Clenters the tube via non-identified transporters and leaks from the tip via channels. Data for $\mathrm{K}^{+}$is still controversial. (C) Electric equivalent of the hypothesized polarization of transporters in the tobacco pollen tube. (D) Analysis of transcriptome for ion transporters in the pollen of Arabidopsis. Dark grey areas represent the total number of genes categorized for each family of transporters in the Arabidopsis genome. Small squares represent the ones present in pollen, colored from red lover-expressed in relation to the vegetative tissues) to blue (under-expressed). (data from Pina et al., 2005; see also Becker and Feijó, 2007).
A

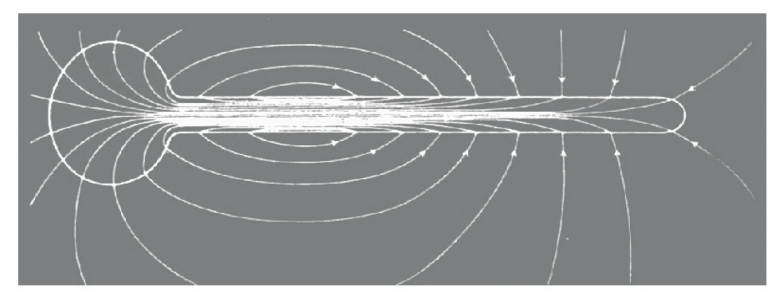

B

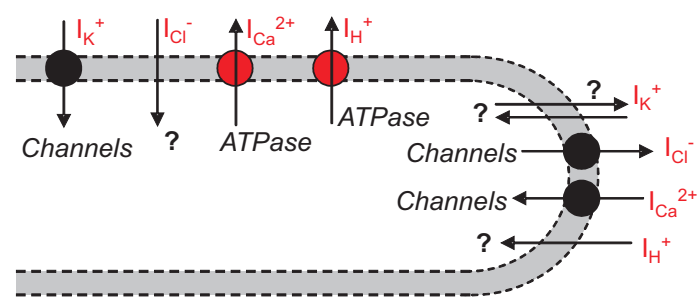

C

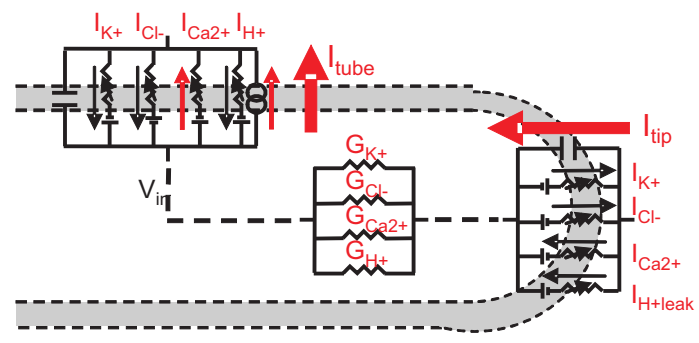

D

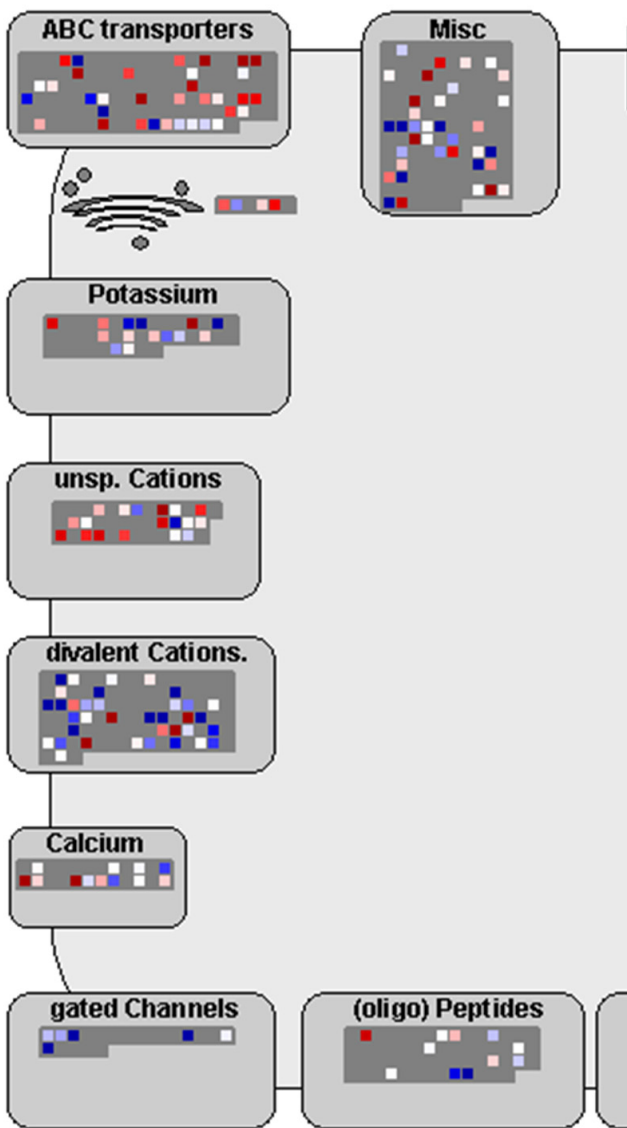

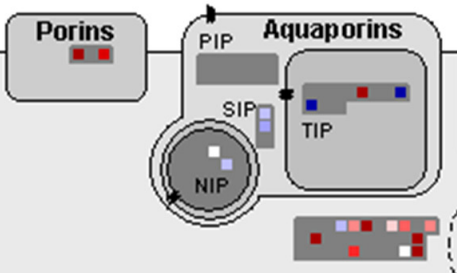
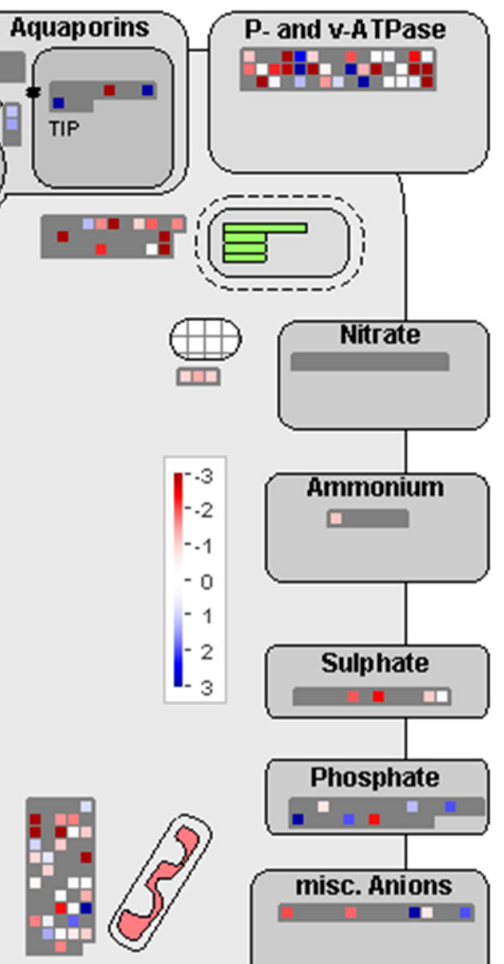

misc. Anions 
able to drive and balance these charge fluxes (Messerli et al., 1999). Although our group intensively worked on $\mathrm{K}^{+}$fluxes around pollen tubes, the reproducibility of these tip influxes remains challenging. It is noteworthy that the experiments published were performed using the ion-vibratingprobe technique, with very high buffer (MES $5 \mathrm{mM}$ ), but more importantly, high $\mathrm{K}^{+}$backgrounds (possibly over $3 \mathrm{mM}$ ). The incorporation of large quantities of buffer in the bath medium has been simulated and experimentally confirmed to produce large artifacts using ion-vibrating probes (Kunkel et al., 2001). In all likelihoods the same sort of artifacts are theoretically expected for measures on high $\mathrm{K}^{+}$backgrounds. In these conditions, changes of the measured electric potentials with the probe in relation with $\mathrm{K}^{+}$concentration in the media are expected to be very small, and with significantly low $\mathrm{S} / \mathrm{N}$ ratios, turning these results difficult to interpret. It is curious to note that the group of Robinson demonstrated that the experimental conditions used to measure these $\mathrm{K}^{+}$fluxes - i.e. high MES concentration do not necessarily fit with a precise measurement using the ion-specific vibrating probe technique, an argument used to dismiss a role for $\mathrm{Cl}^{-}$in pollen tube growth (Messerli et al., 2004).

The possible consensus of all this information is gathered in Fig. 1B, and the equivalent electric diagram in Fig. $1 \mathrm{C}$. So how do all these fluxes cope with the original finding that pollen tubes behave as an electric dipole? The charge movement across the pollen tube must be carried by the ions fluxes described above. Nevertheless, only a fraction of these ion fluxes is involved in the net charge movement across the pollen PM. For instance, in the PM of the tube, charge effluxes driven by the proton-pump may be partially compensated by cationic influxes, such as $\mathrm{K}^{+}$. Furthermore, being an open system, pollen tubes have net accumulations of certain ions and net extrusion of others, a notion which stems as almost intuitive from the fact that ion fluxes at the tip and at the tube are both qualitatively and quantitatively different. Consequently, the net charge flux at the tube can be driven by ions different than the ions driving the net charge influx at the tip (Fig. 1 A-C). Potassium substitution and addition experiments have lead to previous conclusions that $\mathrm{K}^{+}$influx at the tip could be responsible for the net charge influx (Weisenseel and Jaffe, 1976). Besides the issues related to the use of the original voltage vibrating probe to infer on ion specificity, the data discussed in the previous paragraphs, namely the presence of proton influxes and strong anion effluxes at the tip, make this model no longer satisfactory. Any accurate description of the specific mechanisms underlying the differential polarization of fluxes must have into consideration what is nowadays known about the specific ion transporters expressed in pollen for each of the involved ions (Fig.1D). This is a challenge
B
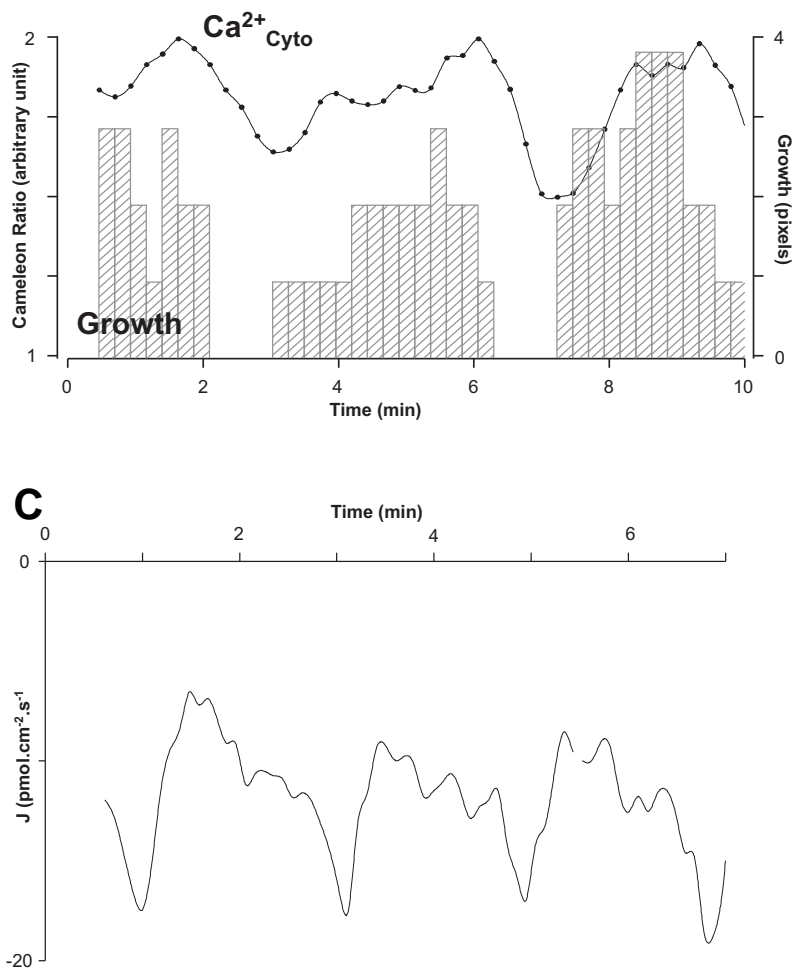

$-20$

Fig. 2. Intracellular $\mathbf{C a}^{2+}$ and $\mathbf{C a}^{2+}$ fluxes at the tip of the tobacco pollen tube. (A) Time-course variations of cytosolic free $\mathrm{Ca}^{2+}$ in a tobacco pollen tube as revealed by confocal ratiometric imaging fluctuations (line) and growth rate (bars) in a tobacco pollen tube. Note that the growth rate and intracellular oscillations are grossly in phase, but the growth peak seems to slightly precede the intracellular $\mathrm{Ca}^{2+}$ peak (Michard et al., 2008). (C) Oscillating $\mathrm{Ca}^{2+}$ influx recorded at the tip of a tobacco pollen tube using a $\mathrm{Ca}^{2+}$-vibrating probe.

that should be interiorized by every group in the field if one aims to escape the vicious circle of continuous contention based on qualitative results, basically obtained through different experimental conditions based on personal or historic instrumental interpretations and consequently, independent qualitative subjective reading of the data in terms of the underlying molecular mechanisms.

\section{Ion transporters and cell growth}

Ion transporters are both involved in signaling, via $\mathrm{Ca}^{2+}$ and $\mathrm{H}^{+}$ or membrane potential $(\mathrm{E} m)$, and in cell growth, by permitting the accumulation of ions inside the cell, and/ or promoting turgor pressure. Therefore they are an intrinsic part of the growth machinery while playing a central role in triggering different signaling cascades. Remarkably, ion transporters must achieve these multi-functional roles by self-organization of the existing proteins in the pollen grain before dehydration and release into the atmosphere, or by the ones immediately expressed after germination, thus possibly creating an original paradigm for selforganization of dehydrated germinating cells (Feijó et al., 1995). It might be noted that ion transporters act in systems, and that the activity of all the ion transporters in one system are inter-dependent. As described in the following section, ion transporters 
activity affects many biophysical parameters, which in turn could all take part in the fundamental features underlying cell growth and signaling. But first one must describe their known effects on the intracellular milieu.

\section{Cytoplasmic polarization and second messengers}

Many studies showed that calcium displays a concentration gradient at the tip of the pollen tube, namely by using radiolabeled calcium (Jaffe et al., 1975) or synthetic fluorescent probes (Reiss and Herth, 1978; 1979; 1985). These methods were later refined to demonstrate the presence of a tip-focused cytosolic free $\mathrm{Ca}^{2+}$ gradient, a much more important finding for issues of signaling than total cytoplasmic $\mathrm{Ca}^{2+}$ (Obermeyer and Weisenseel, 1991; Rathore et al., 1991; Miller et al., 1992; Malhó et al., 1994; Pierson et al., 1994; 1996; Messerli and Robinson, 1997; Holdaway-Clarke et al., 1997; Messerli et al., 2000). More recently, genetic probes were introduced, confirming this pattern (Watahiki et al., 2004; Iwano et al., 2004; see Fig. 2). The precise role of the extracellular $\mathrm{Ca}^{2+}$ influx at the tip in the $\mathrm{Ca}^{2+}$ gradient establishment is still unclear (Holdaway-Clarke et al., 1997; Holdaway-Clarke and Hepler, 2003). Treatment of pollen tubes with $\mathrm{Ca}^{2+}$ channel inhibitors disrupts the $\mathrm{Ca}^{2+}$ gradient, demonstrating that the $\mathrm{Ca}^{2+}$ gradient is apparently triggered by its influx (Obermeyer and Weisenseel, 1991; Malhó et al., 1995). Nevertheless, a role for $\mathrm{Ca}^{2+}$ internal stores was also proposed as an alternative explanation for the gradient establishment (HoldawayClarke et al., 1997). In summary, the $\mathrm{Ca}^{2+}$ gradient at the tip seems to be essential for the pollen tube to grow, and in addition to act as modulator of the directional changes of growth, with some evidence showing a possible causal role on the redirectioning response, as the delocalization of this gradient precedes pollen tube turning (Malhó and Trewavas, 1996).

Cytoskeleton dynamics / exocytosis (Roy et al., 1999; Parton etal., 2003; Hwang et al., 2005), endocytosis (Helling et al., 2006) and ion transporters (Becker et al., 2004) have been proposed as the physiological effectors of the $\mathrm{Ca}^{2+}$ gradient. The signaling cascades downstream $\mathrm{Ca}^{2+}$ are multiple (Malhó et al., 2006), and may imply phosphorylation through $\mathrm{Ca}^{2+}$-dependent-protein kinases (Yoon et al., 2006), small GTPases (Gu et al., 2005) or calmodulin (Rato et al., 2004). The general scheme of the $\mathrm{Ca}^{2+}$ dependent signaling cascades is largely unknown in pollen, despite the obvious intercalation and ramification of the various networks (see e.g., Holdaway-Clarke and Hepler, 2003).

In parallel, $\mathrm{H}^{+}$enters the tip, but leaves steadily through tube shank and grain PM (Fig. 1B). Imaging studies revealed $\mathrm{a} \mathrm{H}^{+}$ gradient inside the pollen tube, with an acidic end located at the tip, and an alkaline zone grossly corresponding to the clear zone of large organelles in lily (Fig. 4A; Feijó et al., 1999). The $\mathrm{H}^{+}$influx at the tip has been suggested to be partly responsible for the establishment of this gradient, which in turn may be responsible for some of the features of the actin cytoskeleton in that area (Cárdenas et al., 2005; Lovy-Wheeler et al., 2006). A role for internal $\mathrm{H}^{+}$stores (mitochondria, vacuole and secretory vesicles notably) is also expected for the maintenance of this gradient (Feijó et al., 1999). Most importantly, the specific location on the plasma membrane of the $\mathrm{H}^{+}$-pumps is predicted to be of pivotal importance for the dynamic regulation of this gradient (Feijó et al., 1999; 2004; Certal et al., 2008).

Being the two best cytosolic free ions studied so far, one may speculate about the synergistic relationships between $\mathrm{Ca}^{2+}$ and $\mathrm{H}^{+}$? The presence of both $\mathrm{H}^{+}$and $\mathrm{Ca}^{2+}$ standing concentration gradients is a sine qua noncondition for pollen tubes to grow, and both have sometimes overlapping functional targets in the cell. Of special note is actin dynamics and transporters, an aspect argued to defend the point of a synergistic role between both ions (LovyWheeler et al., 2006). The imaging of cytosolic $\left[\mathrm{Ca}^{2+}\right]$ and $\left.\mathrm{CH}^{+}\right]$ using genetic markers shows that the two gradients display different spatial patterns. In tobacco, the $\mathrm{Ca}^{2+}$ gradient displays a cortically focused shape, slightly de-focused from the tip (Fig. 2), while the $\mathrm{H}^{+}$gradient shows up as an inverted-cone (Fig. 3)(Michard et al., 2008). Of special notice, the $\left[\mathrm{Ca}^{2+}\right]$ imaging was done using particularly stringent confocal imaging. We contend that this differential spatial patterning of these two second messengers may play a role in the pollen tube polarization and spatial organization of the tip domain.

\section{Does a hydrostatic field operate at the pollen tube?}

There is no correlation between the absolute turgor pressure and pollen growth rate, but a minimum intracellular turgor pressure is required for pollen tube growth (Benkert et al., 1997). The role of turgor pressure in the mechanical driving of the pollen growth is therefore ill-defined. It is noteworthy that the measured turgor pressure is substantially inferior to the external osmotic pressure needed to plasmolyse the cell (Benkert et al., 1997). This can be a clue that other hydrostatic forces take place inside the pollen tube.

Despite the fact that no experimental confirmation was yet published, it has been contended that the pollen tube displays a unique volume of vacuole-free cytoplasm (Mascarenhas, 1993). This cytoplasmic fraction is by and large devoid of any large organelle thereby being able to support water-potential differentials. In this space, local hydrostatic forces can not be neglected, such as the ones that derive from hydrogel interactions of macromolecules, namely globular proteins, with water. Note also that anions massively leave the tip. Predictably this increases the water-potential inside the cytoplasm near the apical PM (Zonia et al., 2001, 2002). The large volume of the cytoplasm between the tip PM and the vacuole may then allow the establishment of a water-potential gradient inside the cytoplasm and the associated hydrostatic forces. These mechanical forces are expected to be directed from the tube in the apical direction and may modulate locally the mechanical pressure at the tip PM.

\section{The molecular identity of ion transporters in the plasma membrane of pollen tubes}

\section{The proton-pump is restricted to the basal plasma membrane regions and energizes the plasma membrane}

Pollen germination is dependent on the activity of $\mathrm{H}^{+}$-pumping, a finding based on various observations, namely on the general correlation between activators and inhibitors of these pumps and germination rates. One of the first reports was in olive, where germination rates correlated with $\mathrm{H}^{+}$extrusion, as measured by the medium acidification, either by stimulating with fusicoccin or inhibiting with vanadate (Rodríguez-Rosales et al., 1989). In various other species, experimental and genetic conditions seem to corroborate this early finding (Feijó et al., 1992; Zhao et al., 2000; Robertson et al., 2004; Lovy-Wheeler et al., 2006; Certal et 
al., 2008). Direct demonstration of a $\mathrm{H}^{+}$-pump activity, agonized by fusicoccin and inhibited by vanadate, has been made by patchclamping pollen tube protoplasts (Gehwolf et al., 2002).

Enzyme cytochemistry and immunochemistry were also used to reveal the differential presence of an ATPase activity in the pollen grain and tube PM (Feijó et al., 1992; Obermeyer et al., 1992; see Fig. 4E). Generally speaking, the PM of pollen tubes displays a net efflux of $\mathrm{H}^{+}$as measured using a proton-specific vibrating probe both in lily (Fig. 4B; Feijó et al., 1999) and tobacco (Fig. 4F; Certal et al., 2008). In Lilium, the $\mathrm{H}^{+}$-efflux has a maximum intensity at around $50 \mu \mathrm{m}$ far from the tip (Feijó et al., 1999). This $\mathrm{H}^{+}$efflux peak corresponds to the location of an alkaline domain in the cytoplasm, as measured using the fluorescent pH-probe BCECF-10.000 Dextran (Fig. 4A; Feijó et al., 1999). This suggests that $\mathrm{H}^{+}$-pumps are active on the tube $P M$ and deplete the cytoplasm of $\mathrm{H}^{+}$. Confirming the assumption, treatment by fusicoccin (that activates the $\mathrm{H}^{+}$-pump) alkalinizes the pollen tube cytoplasm (Lovy-Wheeler et al., 2006). A theoretical prediction that could explain these results would be the specific exclusion of these pumps from the apical PM (Fig. 4C; Feijó et al., 1999, 2004).

Various molecular studies confirmed the presence of $\mathrm{H}^{+}$pumps and ultimately the prediction that they are absent from the apical domain of the PM. Arabidopsis pollen expresses several isoforms of the $\mathrm{H}^{+}$-pumps (the $A H A$ gene family) that could account for this ATPase activity, some being pollen specific and/ or highly expressed, most notably AHA6 (Pina et al., 2005). Lefebvre et al. (2005) cloned it and showed by immuno-localiza-

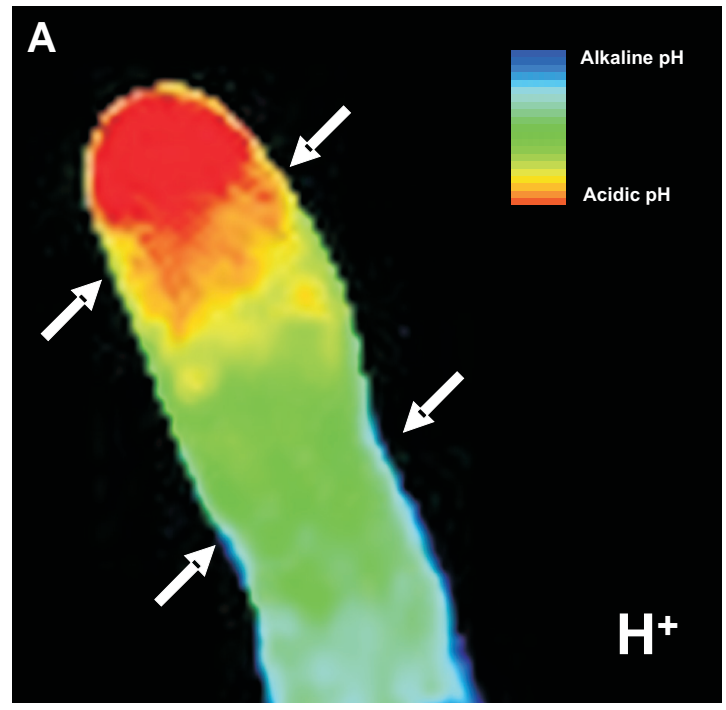

Fig. 3. Cytosolic $\mathrm{pH}$ and $\mathrm{H}^{+}$fluxes at the tip of tobacco pollen tube. (A) Intracellular $\mathrm{pH}$ of a tobacco pollen tube as imaged with the GFPderived pH-sensor "pHluorin" (Miesenbock et al., 1998). The image was obtained by ratiometric widefield microscopy, and depicts a typical initiation of a growing cycle, corresponding to a massive influx of $\mathrm{H}^{+}$at the tip, forming a comet-like gradient of acidity. Note however that the flanks of this gradient are significantly more alkaline than the core (arrows), revealing that the sub-membranar volume is likely always less concentrated in $\mathrm{H}^{+}$(i.e. relatively more alkaline) as compared to the tube core (Michard et al., 2008). (B) Cytosolic pH fluctuations (line) and growth rate (bars) of a tobacco pollen tube. The dynamic behavior is qualitatively similar to the one of $\mathrm{Ca}^{2+}$, but with slightly different delays and oscillation properties. (C) $\mathrm{H}^{+}$influxes recorded at the tip of tobacco pollen tube using a $\mathrm{H}^{+}$-specific vibrating probe. tion that its putative orthologue in Nicotiana plumbaginifolia, Ntpma5, is specific of pollen, and absent from the tip. More recently, we cloned another orthologue from tobacco, which was baptized as Nt AHA (Nicotiana $\mathrm{H}^{+}$-ATPase; Certal et al., 2008). The sub-cellular localization of $\mathrm{Nt} \mathrm{AHA} \mathrm{was} \mathrm{studied} \mathrm{by} \mathrm{GFP}$ fusion, and shown to be, even on over-expressing conditions, by and large absent from the apical PM (Fig. 4D).

\section{The proton-pump energizes the plasma membrane of the pollen tube}

The electric membrane potential $(\mathrm{E} m)$ has been measured in pollen tubes, by impaling an electrode 50 to $100 \mu \mathrm{m}$ far away from the tip in lily (Weisenseel and Wenisch, 1980) and Arabidopsis (Mouline et al., 2002). Although the method underestimates the measured potential (Gassmann and Schroeder 1994), the values reported are slightly below the equilibrium potential for $\mathrm{K}^{+}$, suggesting the presence of an active transporter on the tube PM. Moreover, tube $\mathrm{E} m$ is sensitive to external $\mathrm{pH}$, suggesting a role for $\mathrm{H}^{+}$fluxes in its establishment, as well as temperature, suggesting the presence of an active transport system (Weisenseel and Wenisch, 1980). All together, these data strongly suggest that some $\mathrm{H}^{+}$-pump system energizes the tube PM.

The role of the $\mathrm{Ca}^{2+}$-ATPase in membrane energization has not been considered so far. Yet, genetic evidence showed a function for one such pump, proven to be necessary for pollen development and growth, and expressed evenly on the tube PM, including the apical domain (Schiott et al., 2004). A weak $\mathrm{Ca}^{2+}$ efflux has been recorded at the tube shank, but the role of $\mathrm{Ca}^{2+}$
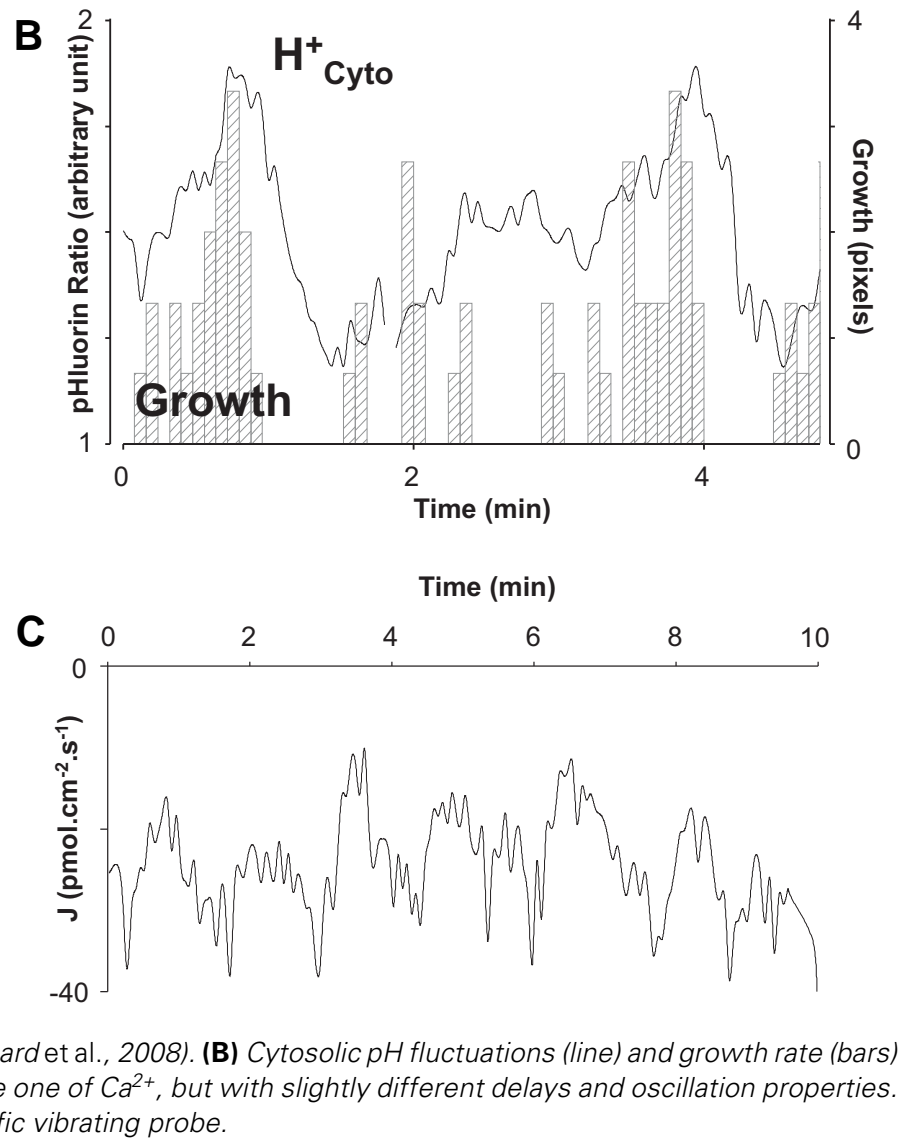
efflux in PM polarization is expected to be marginal. Moreover, electrical membrane potential $(\mathrm{E} m)$ is poorly dependent on external $\mathrm{Ca}^{2+}$ concentration (Weisenseel and Wenisch, 1980). The mechanistic implications of this pump remain thus to be better established, but its importance is well spelled out on the consequences of its genetic manipulation.

\section{Proton pump-dependent ion absorption by the tube}

Being above the equilibrium-potential for $\mathrm{K}^{+}$, the tube $\mathrm{E} m$ can, perse, implicate the passive entry of this cation. Supporting this idea, the membrane potential of the tube is strongly dependent on external $\mathrm{K}^{+}$(Weisenseel and Wenisch, 1980). Using a pipette impalement technique in voltage-clamp mode, a large conductance for $\mathrm{K}^{+}$was also described across the tube PM (Becker et al., 2004).

Pollen tubes can grow under extremely low external $\mathrm{K}^{+}$concentrations, the only consequence being a slightly slower growth rate. Under low $\mathrm{K}^{+}$growth conditions they become very sensitive to $\mathrm{K}^{+}$channel inhibitors (Fan et al., 2001; Mouline et al., 2002). This suggests that these cells possess a powerful $\mathrm{K}^{+}$uptake system, in which $\mathrm{K}^{+}$channels may play a significant role.

The transcription of several $\mathrm{K}^{+}$-channels has been identified in pollen using RT-PCR (Mouline et al., 2002; Becker et al., 2004) or micro-arrays analysis (Becker et al., 2003; Honys and Twell, 2004; Pina et al., 2005). Using pharmacological studies coupled to genetic and electrophysiological approaches, a $\mathrm{K}^{+}$channel from the Shakerfamily (SPIK) has been shown to play a role in this high affinity $\mathrm{K}^{+}$uptake in Arabidopsispollen (Mouline etal., 2002), specially on hyper-polarization conditions. Another member of the Shakerfamily, AKT5, is also expressed in pollen (Becker et al., 2004). The functional properties of AKT5 are unknown. Other members from the family may also play a role (Mouline et al., 2002; Becker et al., 2004). More recently, a K+ channel, AtTPK4, from the KCO/TPK family was shown to be responsible for a marginal proportion of the tube $\mathrm{K}^{+}$conductance (Becker et al., 2004). Other transporters, from $\mathrm{CHX}$ or $A K \mathrm{KT} / A$ AKUP/HAK families for instance, may contribute to the $\mathrm{K}^{+}$fluxes at the tube PM (see below).

\section{Inorganic anions enter the tube via an unidentified mecha- nism}

An anion influx, most notably carried by chloride, was measured at the tube region in lily and tobacco (Zonia et al., 2002). This influx goes against the expected electrochemical gradient, as estimated using data published in Weisenseel and Wenisch (1980), Zonia et al. (2002) and Messerli et al. (2004). This implies that anions enter the tube viaan active or coupled mechanism. No further experimental data is available on anion absorption by the pollen tube, but it is tempting to hypothesize that anions enter the tube region viaa $\mathrm{H}^{+}$-anion co-transporter, as they do in other plant cells. Several molecular candidates are present in the pollen transcriptome.

\section{Different domains, different mechanisms: a passive ion transport system in the apical plasma membrane}

From the previous paragraph it stems that most molecular components that carry out the ionic fluxes in the pollen tube system still remain to be characterized. Some predictions, how- ever, can be tested from its expected behavior.

With no $\mathrm{H}^{+}$-pump energization, ion fluxes at the tip of the pollen tube are largely expected to be passive. Indeed, $\mathrm{Ca}^{2+}$ and $\mathrm{H}^{+}$ fluxes flow in the direction of their electrochemical gradients. Anion efflux at the tip has also been shown to be inhibited by direct channel inhibitors (Zonia et al., 2002).

As stated above, $\mathrm{H}^{+}$enters the tip passively. Non-selective cation channels (NSCCs) as well as co-transporters of the $\mathrm{H}^{+} / \mathrm{X}$ class may participate to these fluxes. Co-transporters and exchangers could play an important role in $\mathrm{H}^{+}$fluxes at the tip, as suggested by the fact that the family of the $\mathrm{CHX}$ transporters is clearly over-represented in pollen, with most of these genes exclusively expressed there (Cellier et al., 2004; Sze et al., 2004; Pina et al., 2005; Bock et al., 2006). CHX transporters are similar to animal $\mathrm{H}^{+} / \mathrm{Na}^{+}-\mathrm{K}^{+}$exchangers and have been suggested to play a role in pollen $\mathrm{K}^{+}$homeostasis during growth.

The $\mathrm{TRH} 1$ gene codes for a co-transporter $\mathrm{K}^{+}-\mathrm{H}^{+}$from the AKT/AIKUP/HAK family. Its disruption inhibits the root-hair growth (Rigas et al., 2001; Ahn et al., 2004). Increasing the external $\mathrm{K}^{+}$ concentration does not revert the phenotype (Desbrosses et al., 2003). This strongly suggests a role of $\mathrm{TRH} 1$ in the $\mathrm{H}^{+}$influx across the root-hairs $\mathrm{PM}$ which is, like in pollen, restricted to the tip (Gilroy and Jones, 2000; Carol and Dolan, 2002). Members from the $\mathrm{TRH} 1$ family are expressed in pollen (Pina et al., 2005).

There is still no molecular evidence for a spatial segregation of $\mathrm{K}^{+}$channels in the pollen tip $v s$. tube and grain. $\mathrm{K}^{+}$conductance recorded using patch-clamp on the grain or on the tube/ tip revealed some electro-physiological differences, suggesting that the channels/ transporters active in these regions are different (Fan et al., 1999; Fan et al., 2001; Fan et al., 2003; Griessner and Obermeyer, 2003). Alternatively, one can not discard the hypothesis that the $\mathrm{K}^{+}$transporters and channels may be the same in the tube and the tip regions. On such model, depending on the direction of the potassium flux at the tip, outward channels or transporters, such as SKOR or $\mathrm{CHX}$, could play a dominant role over inward transporters, such as SPIK or $A K K T / A K K U P / H A K$.

Anions leave the pollen tube by the tip (Zonia et al., 2002). These fluxes are inhibited by pharmacological agents selective for animal chloride channels, and particularly for channels from the CFTR-family (belonging to the ABC-transporter super-family).

No molecular data is available on the identity of the anion channel(s) vs. symporter vs. exchanger at the tip PM. One member from the ABC family, AMRP5, has been reported to play a role in anion permeability regulation in guard-cells (Suh et al., 2007). Although the protein was not shown to mediate anion transport, proteins from the family are interesting candidates to the anion channels of pollen. AMRP5, in addition to two other members of the MRP-family, are expressed in pollen (Pina et al., 2005). Recently, a gene, $S L A C 1$ which is essential for cellular anion homeostasis, has been identified in Arabidopsis. SLAC1 is a distant homologue of bacterial and fungal dicarboxylate/ malic acid transporters. Its disruption affects stomatal closure and decreases anion conductance in these cells, suggesting that it encodes for an anion channel (Negi et al., 2008; Vahisalu et al., 2008)

$\mathrm{Ca}^{2+}$ enters pollen tubes almost exclusively by the tip (Kuehtreiber and Jaffe, 1990; Pierson et al., 1994; Malhó et al., 1995; Messerli and Robinson, 1997; Messerli et al., 1999). 
Channels mustmediate these $\mathrm{Ca}^{2+}$ influxes. This statement is based on pharmacological as well as electrophysiological results. Hence, as recorded by vibrating probes, $\mathrm{Ca}^{2+}$ fluxes are sensitive to a broad spectrum of $\mathrm{Ca}^{2+}$ channel inhibitors (nifedipin, $\mathrm{Gd}^{3+}, \mathrm{La}^{3+}$, verapamil, etc; see e.g. Reiss and Herth, 1985; Geitmann and Cresti, 1998). On the other hand, single-channel traces of channels permeable to $\mathrm{Ca}^{2+}$ have been recorded on pollen protoplasts (Dutta and Robinson, 2004; Wang et al., 2004). The channel described by Wang et al. (2004) is inhibited by $\mathrm{La}^{3+}$ as well as by $\mathrm{Gd}^{3+}$ and activated by hyperpolarization. Dutta et al. (2004) described a channel strongly selective for $\mathrm{Ca}^{2+}$ over $\mathrm{K}^{+}\left(\mathrm{pCa}^{2+} / \mathrm{pK}^{+}=98\right)$ and activated by membrane stretch. Macroscopic $\mathrm{Ca}^{2+}$ currents activated by hyperpolarization have been described in Lilium davidiiand Arabidopsisgrains as well as in Pyrus pyrifoliatube protoplasts (Shang et al., 2005; Qu etal., 2007; Wu et al., 2007). The selectivity of these currents, as well as their physiological role remains to be elucidated.

The molecular identity of the channels responsible for the $\mathrm{Ca}^{2+}$ entry into the pollen in particular, and in plant cells in general, is largely unknown, and identification of $\mathrm{Ca}^{2+}$-selective channels, or cation-channels permeable to $\mathrm{Ca}^{2+}$ in plants is one of the hot topics in the field (Hetherington and Brownlee, 2004).

Recent studies have pointed out three families of cation channels which share strong sequence homology with animal channels and constitute good candidates to account for $\mathrm{Ca}^{2+}$ influxes through the tip PM: the cyclic-nucleotide gated channels (cNGC), the ionotropic amino-acid receptors (iGluR) and the annexines (see Demidchik and Maathuis, 2007). The disruption of a member of the cyclicnucleotide-gated channels family (cNGC18) induces male sterility, and the expression of this channel in $E$. colïincreases $\mathrm{Ca}^{2+}$ uptake by the bacteria, suggesting that CNGC18 may participate in calcium influxes at the tip (Frietsch et al., 2007).

\section{Regulation of ion transport systems in the pollen tube}

The pollen tube polarization correlates with a sub-cellular patterning of central biophysical parameters such as $\mathrm{Ca}^{2+}$ concentration, $\mathrm{pH}$, and hypothetical hydrostatic and electric fields. These parameters display gradients along the pollen tube/ tip that are necessary for cellular growth. As described above, ion transporters play a central role in the local control of these parameters and in the establishment of the gradients. On the other hand, they are regulated by these factors. By consequence, ion transport systems should be strongly integrated, and a full understanding of the way they work implies the characterization of these complex regulatory connections. If these imply complete regulatory loops, in which transporters may be simultaneously triggers and effectors of a specific ionic choreography in space and time, the place is reserved for them to perform a crucial and fundamental level of developmental regulation.

\section{Electrical membrane potential}

The electrical membrane potential $(\mathrm{E} m)$ integrates all the ion fluxes at the PM and is thereby a key parameter in cell biology. $\mathrm{E} m$ plays a major role in ion transport regulation and consequently in cell sensing and adaptation ( $v s$. response) to environment. This was well demonstrated, for example, in the guard-cell system (Thiel et al., 1992; Roelfsema and Hedrich, 2005). In pollen tubes, data on the transporter regulation by $\mathrm{E} m$ is scarce, but the hints are multiple.

$\mathrm{K}^{+}$conductance (Obermayer and Blatt, 1995; Fan et al., 1999;
Fan et al., 2001; Fan et al., 2003; Griessner and Obermeyer, 2003; Becker et al., 2004) and $\mathrm{K}^{+}$channels (Mouline et al., 2002) are regulated by $\mathrm{E} m$ in pollen.

$\mathrm{Ca}^{2+}$ channels have been identified by patch-clamp in the pollen grain. Among them, one has been shown to be activated by hyperpolarization (Wang et al., 2004). At the macroscopic level, hyperpolarization-activated currents have been reported (Shang et al., 2005; $\mathrm{Qu}$ et al., 2007; Wu et al., 2007). In root-hairs, the main $\mathrm{Ca}^{2+}$ conductance is also activated by hyperpolarization (Very and Davies, 2000). While without positive identification yet, anion channels might also prove to be voltage-gated (Barbier-Brygoo et al., 2000).

\section{Membrane stretch}

Membrane stretch has been proposed to play a role in the pollen tube growth regulation for a long time (Feijó et al., 1995), mostly based on the striking effect of typical (but not specific) stretch channel inhibitors, like the lanthanides $\left(\mathrm{Ld}^{3+}, \mathrm{Gd}^{3+}\right)$. Supporting this idea, stretch-gated channels have been proposed, namely $\mathrm{KK}^{+}$and a $\mathrm{Ca}^{2+}$ channel (Dutta and Robinson, 2004). Proper characterization of stretch-activated channels is still a matter of some debate, and confirmation of these channel activities by other groups would help to settle this concept. Consistent with the concept of a mechanical triggering of some sort is the finding of $\mathrm{C} \mathrm{Ca}^{2+}$ channel regulated by actin (Wang etal., 2004). Although the two mechanisms (stretch- and actin- regulation) are not related at the molecular level, both are dependent on mechanical forces, and both could be engaged in similar processes in the pollen growth.

\section{pH}

As any other bona fideglobular protein, transporters are sensitive to extracellular and cytosolic $\mathrm{pH}$.

$\mathrm{H}^{+}$-ATPases are regulated by both cytosolic $\mathrm{pH}$ and $\mathrm{H}^{+}$electrochemical gradient across the PM (Palmgren and Christensen, 1994).

$\mathrm{K}^{+}$conductance is activated by an extracellular acidification in the pollen grain and tube (Fan et al., 1999; Fan et al., 2001; Fan et al., 2003; Griessner and Obermeyer, 2003; Becker et al., 2004). At the molecular level, two Shaker channels are expressed in the pollen tube; SPIK and SKOR are sensitive to external acidification. Whereas SPIK is activated (Mouline et al., 2002), SKOR is inhibited by external protons (Lacombe etal., 2000). Moreover, the SKOR channel is also inhibited by internal acidification (Lacombe et al., 2000). In contrast, the At TPK4 channel, also involved in the pollen tube $\mathrm{K}^{+}$conductance, is blocked by an internal acidification (Becker et al., 2004).

\section{Potassium}

The consideration of $\mathrm{K}^{+}$as a regulator of plant ion transporters is new. Recently, two transporters expressed in pollen have been shown to be regulated by $\mathrm{K}^{+}$: a proton-pump (Buch-Pedersen et al., 2006) and the SKOR $\mathrm{K}^{+}$channel (Johansson et al., 2006; Liu et al., 2006).

\section{$\mathrm{Ca}^{2+}$ and post-translational modifications}

Many transporters are regulated by $\mathrm{Ca}^{2+}$; directly via fixation on the protein core (Becker et al., 2004), or indirectly, via the complex signaling pathways downstream of $\mathrm{Ca}^{2+}$ elevations. For example, the AKT1 mRNA has been detected in pollen by RT-PCR, and this channel is known to be regulated by $\mathrm{Ca}^{2+}$-dependent phosphorylation (Li et al., 2006).

The regulation of pollen transporters by $\mathrm{Ca}^{2+}$ is poorly docu- 
mented, but given its central influence in many physiological responses, it is generally accepted that it must play some sort of direct or indirect role. Recently, the AtTPK $4 \mathrm{~K}^{+}$channel has been shown to be regulated by $\mathrm{Ca}^{2+}$ (Becker et al., 2004).

\section{Ion transporter network and cross-signaling: the need for mod- els and systems approaches}

The regulation parameters we just discussed, though intrinsically important, are unlikely to fill the complete list of possible effectors and affecters of ion channels. Of sure importance, but even less characterized, should be the influence of the endo/ exocytosis and membrane flow systems in general in the correct targeting and assignment of transporters. And the only sure thing is that most factors will interact at some level to create the specific dynamical equilibrium that we recognize as a stable phenotype.

The $\mathrm{Ca}^{2+}$ channel network offers a good example of the complexity of this multi-signaling interaction. $\mathrm{Ca}^{2+}$ channels are sensitive to stretch, membrane potential, and probably cytosolic $\mathrm{pH}$ and $\mathrm{Ca}^{2+}$. In
Fig. 4. The proton-pump plays a central role in proton homeostasis and proton gradient establishment in pollen tube. $\mathrm{A} \mathrm{H}^{+}$- pump system is present and active at the tube plasma membrane (PM) while neither its presence nor its activity seem to be detected at the tip PM. The spatial patterning of the $\mathrm{H}^{+}$-pump activity may be a key point in the pollen tube polarization establishment by defining two transport domains at the pollen PM: an active transport system at the tube, and a passive one at the tip. In turn this may allow the establishment of cytosolic gradients of $\mathrm{H}^{+}$concentration, which may work as a second messenger. (A) Imaging of $\mathrm{H}^{+}$concentration inside one lily growing pollen tube. The picture was taken in wide field using the BCECF-dextran ratiometric dye (Feijó et al., 1999). Note the existence of an alkaline domain in the sub-apical region. The projective nature of the imaging method used does not allow the resolution of the precise geometry of this domain, which may exist at the core, or as a sub-membranar torus. (B) $\mathrm{H}^{+}$ fluxes around a lily pollen tube recorded using a $\mathrm{H}^{+}$-specific vibrating probe. The maximum intensity of $\mathrm{H}^{+}$efflux at the tube spatially correlates with the alkaline domain shown in (A). Note however that the fluxes in this species are of much less intensity than in tobacco, while in contrast, the tube is rather thicker (Feijó et al., 1999). (C) Model of proton homeostasis in lily. This model was created to account for the data exposed in $(A, B)$, and is based on the assumption that the $\mathrm{H}^{+}$-pump should be absent from the tip (Feijó et al. 1999). Because $\mathrm{H}^{+}$ions enter at the tip and leave at the tube, this would create a $\mathrm{pH}$ gradient inside the cytoplasm (i.e. acidic tip). The activity of the $\mathrm{H}^{+}$-pump on the tube PM may locally alkalinize the cytoplasm and create thereby the alkaline domain visible in (A) and the differential sub-membranar domains depicted in Fig. 3A). The existence of similar $\mathrm{H}^{+}$ loops in root hairs has led to the prediction that this could constitute a more generalized mechanism of polarity in apical growing cells (Palmgren, 2001; Feijó et al. 2004). (D) Cloning of the $\mathrm{H}^{+}$-pump $\mathrm{Nt}$ AHA (Nicotiana $\mathrm{H}^{+}$-ATPase) from tobacco, confirmed the essential mechanistic prediction of this model. Fluorescence imaging of a growing pollen tube expressing a Nt AHA-GFP chimera (Certal et al., 2008) shows that Nt AHA is selectively excluded from the PM of the apex. (E) Cytochemical analysis of ATPase activity in massulate pollen of the orchid Ophrys lutea (Feijó, 1995). Cerium precipitates corresponding to the activity of $\mathrm{K}^{+}$ dependent ATPases are specifically located in plasma membrane of the pollen grain (GP) but absent from the tip (TP). (F) $\mathrm{H}^{+}$fluxes around a tobacco pollen tube as measured with a $\mathrm{H}^{+}$-specific vibrating probe. The pattern is coincident with the one of distribuition of Nt AHA shown in (D), i.e., where the pump is present there is a net efflux, where the pump is absent, $\mathrm{H}^{+}$leak in the tube. As in lily, $\mathrm{H}^{+}$enter the tip and leave the tube and the grain. $\mathrm{H}^{+}$efflux patterns in lily and in tobacco are different along the tube PM both qualitatively, but mostly in quantitative terms (compare (B, F)). These differences are in good accordance with the differences detected in the imaging of intracellular pH in tobacco as compared with lily (Michard et al., 2008).
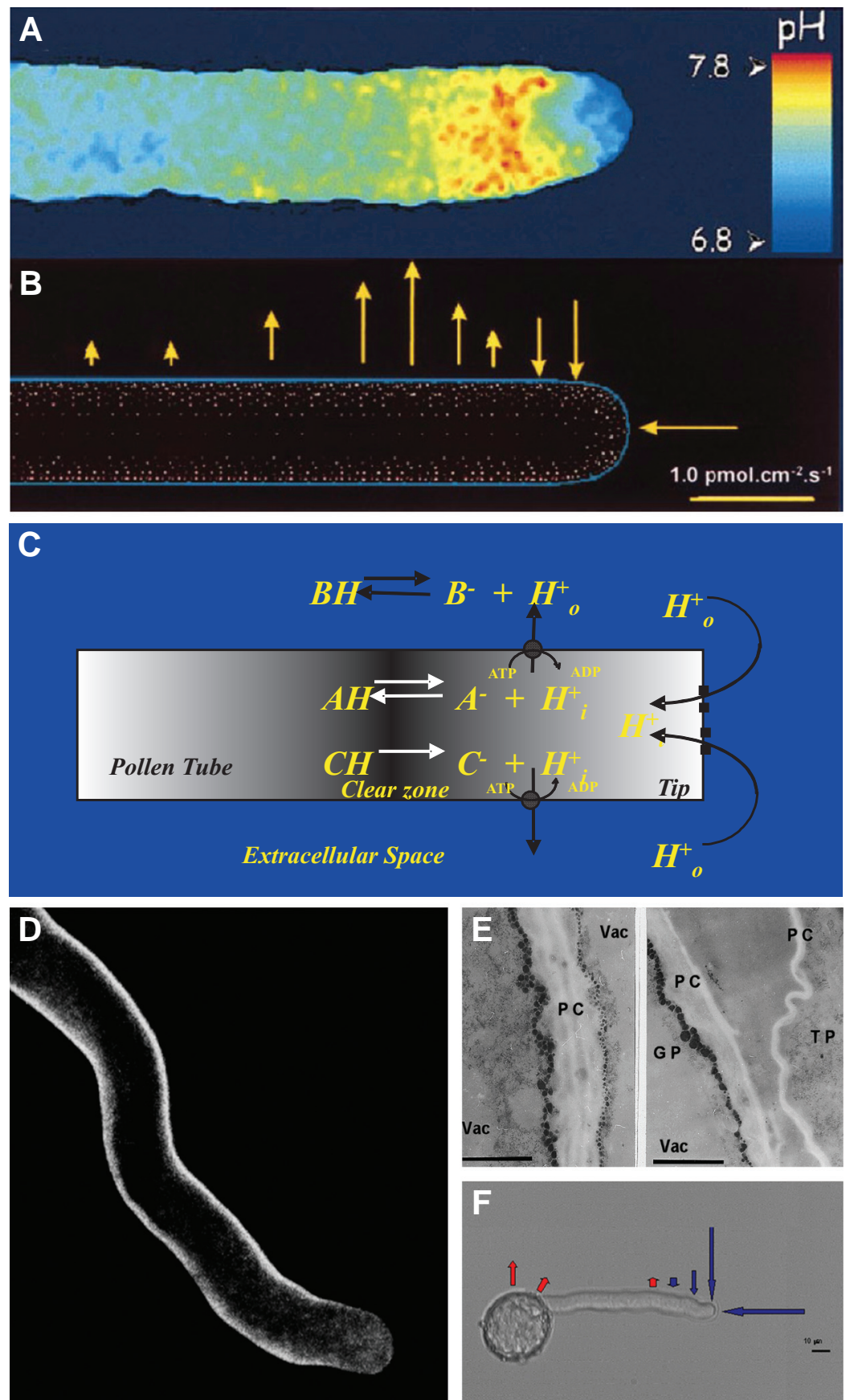
turn, the $\mathrm{Ca}^{2+}$ channels themselves define many features of cell polarization and growth control. Another good example is the $\mathrm{H}^{+}$pump/ $\mathrm{K}^{+}$channel network. They work together in the high-affinity $\mathrm{K}^{+}$uptake by the pollen. A strong $\mathrm{K}^{+}$uptake activity of the $\mathrm{PM}$ is correlated with (i) a strong hyperpolarization (ii) a cytosolic alkalinization and extracellular acidification, and (iii) an increase of the $\mathrm{K}^{+}$concentration inside the cell.

Giving this complexity, the development of robust models and computing algorithms, in a true system's view, may constitute the only way to actually grasp an understanding of the whole transport system in its complexity, and eventually generate testable hypotheses about the complex regulation properties of the ion transporters and their consequences to cellular development and physiology.

\section{A role for ion transporters in the generation of pollen tube oscillations?}

Depending on the growing condition, the pollen tubes of the majority of species so far known will display some sort of periodicity, usually as sustained growth oscillations (Feijó et al., 2001). Almost all physiological parameters of the cell oscillate: the vesicles/ cytoskeleton dynamics (Parton et al., 2001; Hwang et al., 2005; Lovy-Wheeler et al., 2006), ion cytoplasm concentrations $\left(\mathrm{Ca}^{2+}\right.$ and $\mathrm{H}^{+}$gradient; Holdaway-Clarke et al., 1997; Feijó et al., 1999), ion fluxes, and on the top of all, growth. To the extent that all these oscillations share the same central period and comparable relative amplitudes, they seem to be coordinated by the same oscillator (Feijó, 1999; Moreno et al., 2007). For example, ion fluxes at the tip of the pollen tube are strongly correlated, but not in phase, with growth oscillations, fluxes and intracellular concentrations oscillations of $\mathrm{Ca}^{2+}$ (Pierson et al., 1996; Holdaway-Clarke etal., 1997; Messerli etal., 1999; Messerli et al., 2000), $\mathrm{H}^{+}$(Feijó et al., 1999; Messerli et al., 1999; LovyWheeler et al., 2006) and $\mathrm{Cl}^{-}$(Zonia et al., 2002)(see Figs. 2,3).

The mechanism responsible for pollen growth oscillation (the "pacemaker") is unknown. A role for cell-wall (Messerli and Robinson, 2003; Dutta and Robinson, 2004) or reduction potential (Cárdenas et al., 2006) have been proposed. Passive transport systems have been shown - or proposed - to be able to generate spontaneous oscillations (Gradmann etal., 1993). These oscillations play a key role in the guard-cell signaling network, via $\mathrm{Ca}^{2+}$ and $\mathrm{H}^{+}$(Allen et al., 2000; Allen et al., 2001). The transport system at the tip of the pollen is expected to be passive, and a similar mechanism of oscillation generations could occur. $\mathrm{Ca}^{2+}$ channels inhibitors affect the oscillation properties of pollen. (Geitmann and Cresti, 1998), suggesting that $\mathrm{Ca}^{2+}$ channels at the tip are directly involved in the generation of oscillations. External $\mathrm{pH}$ modulates the oscillation parameters of the cells, which suggests that $\mathrm{H}^{+}$transporters, or $\mathrm{H}^{+}$-regulated-transporters may be involved in the generation - or modulation - of oscillations (Holdaway-Clarke and Hepler, 2003).

\section{Conclusions}

\section{A model for pollen electric polarization establishment}

Throughout this review, we have highlighted the importance of ion transporters in the establishment of gradients along the growing pollen tubes. These gradients are essential for the regulation of growth. On the other hand, the polarization of ion fluxes has therefore an obvious physiological role on the spatial patterning of the growing cell, and the establishment and maintenance of its polarity.

The data we reviewed makes it tempting to put up a model for the establishment of electrical polarity in growing pollen tubes (Fig. $1 \mathrm{~B}, \mathrm{C}$ ). In a non-polarized cell, and when the PM is at the resting potential, the ion fluxes that cross it altogether induce no net charge flux. The PM can not support any strong charge gradient (i.e. strong electrical polarization), and once the steadystate $E m$ is reached, the charge efflux driven by the proton-pump is exactly compensated by other ion fluxes. Cation influx (namely $\mathrm{K}^{+}$) and anion efflux via transporters take part in this charge compensation. The PM is permeable to $\mathrm{H}^{+}$, and a "proton shunt" (i.e. inward $\mathrm{H}^{+}$flux through the lipid bi-layer, or specific $\mathrm{H}^{+}$ channels) exactly compensates the $\mathrm{H}^{+}$-pump charge movement in addition to cation influxes/ anion effluxes.

The pollen tube is usually hyperpolarized, and notably above the $\mathrm{K}^{+}$equilibrium potential (Weisenseel and Wenisch, 1980; Mouline et al., 2002). This hyperpolarization can be linked to the $\mathrm{H}^{+}$efflux recorded in this region (Feijó et al., 1999; Certal et al., 2008), and is attributable to $\mathrm{H}^{+}$-pump activity (Weisenseel and Wenisch, 1980; Certal et al., 2008). Consequently there should be a charge depletion in the close vicinity of the $\mathrm{H}^{+}$-pump. The compensation of this charge depletion can be achieved by two competitive mechanisms: (i) the "proton shunt" and (ii) the influx of charges from external media across the tip PM and cytoplasm that electrically links tip and tube. The relative role of these two mechanisms in $\mathrm{H}^{+}$-pump electrical compensation depends respectively (i) on the conductance of the tube PM to $\mathrm{H}^{+}\left(\mathrm{G}^{-1}\right.$ range) (ii) and on the electric conductance of the tip ion-transport system ( $\mathrm{M} \Omega^{-1}$ range) plus the cytoplasm $\left(\mathrm{k} \Omega^{-1}\right.$ range). The relative high electric conductance of both the cytoplasm and the tip PM un-favors the "proton shunt" and induces a net charge flux inside the pollen system. While probably representing a minimal model, we highlight that this model does fit into context all the available data, while allowing a number of testable hypotheses. It is tempting to think that if this model is correct, it would imply the existence of an intracellular physical field through the steady flux of $\mathrm{H}^{+}$and other charged particles. It may be argued that such mechanism should have a theoretical sensitivity to minute intra and extracellular perturbations of the field. If properly connected to the canonical signaling networks, it could constitute a novel fundamental scheme for cell polarization and spatial organization.

\section{A role of transport system polarization in nutrient uptake efficiency?}

In addition, the unique transport system of the polarized cell may have other physiological roles. The co-existence in the same cell of an active transport system (tube) and a passive one (tip) may be responsible for the remarkable efficiency of the pollen tube, but possibly also for root hairs, in the nutrient uptake, particularly $\mathrm{K}^{+}$.

$\mathrm{K}^{+}$is one of the major limiting factors of plant cell growth (Epstein, 1976). The persistence of a sustained growth of pollen under low $\mathrm{K}^{+}$concentrations is striking, and suggests that pollen has an extremely efficient $\mathrm{K}^{+}$uptake system (Mouline et al., 2002). Channels, driven by the $\mathrm{H}^{+}$-pump, play a significant role in the high-affinity $\mathrm{K}^{+}$uptake in pollen. This $\mathrm{K}^{+}$absorption system 
depends on the $\mathrm{H}^{+}$-pump efficiency to hyperpolarize the $\mathrm{PM} . \mathrm{H}^{+}$pump activity, on the other hand, is regulated indirectly by posttranslational modifications (Pertl et al., 2001), and directly, by cytoplasm factors such as $\mathrm{pH}$ (Palmgren and Christensen, 1994; Luo et al., 1999; Palmgren, 2001; Sondergaard et al., 2004). In pollen, AHA3 has notably been shown to be regulated by internal $\mathrm{pH}$ (Palmgren and Christensen, 1994; Robertson etal., 2004). $\mathrm{H}^{+}$influxes at the tip affect $\mathrm{pH}$ in the tube, and acidify the cytosol near the $\mathrm{H}^{+}$-pump. This should activate the $\mathrm{H}^{+}$-pump, by changing the conformation of the protein, and by decreasing the $\mathrm{H}^{+}$-electrochemical gradient across the plasma membrane. Thereby, the passive transport system at the tip is expected to activate the active transport system at the tube and favor nutrient absorption. We note that this mechanism should have direct implications in the unique capacity these cells have to grow at such fast growth rates.

\section{Acknowledgements}

JAF's laboratory is supported by FCT grants POCTI/BIA-BCM/60046/ 2004 and POCTI/BIA-BCM/61270/2004. EM and FA are recipients of FCT fellowships (SFRH/BPD 21056/2004 and 25835/2005 respectively). We thank Jörg Becker for Fig. 1D, and Silvia Costa for Figs. 4 D, F, and both for insightful discussions.

\section{References}

AHN, S.J., SHIN, R., and SCHACHTMAN, D.P. (2004). Expression of KT/KUP genes in Arabidopsis and the role of root hairs in $\mathrm{K}^{+}$uptake. Plant Physiol. 134: 1135-1145

ALLEN, G.J., CHU, S.P., HARRINGTON, C.L., SCHUMACHER, K., HOFFMANN, T., TANG, Y.Y., GRILL, E., and SCHROEDER, J.I. (2001). A defined range of guard cell calcium oscillation parameters encodes stomatal movements. Nature 411: 1053-1057.

ALLEN, G.J., CHU, S.P., SCHUMACHER, K., SHIMAZAKI, C.T., VAFEADOS, D., KEMPER, A., HAWKE, S.D., TALLMAN, G., TSIEN, R.Y., HARPER, J.F., CHORY, J., and SCHROEDER, J.I. (2000). Alteration of stimulus-specific guard cell calcium oscillations and stomatal closing in Arabidopsis det3 mutant. Science 289: 2338-2342.

BARBIER-BRYGOO, H., VINAUGER, M., COLCOMBET, J., EPHRITIKHINE, G., FRACHISSE, J., and MAUREL, C. (2000). Anion channels in higher plants: functional characterization, molecular structure and physiological role. Biochim. Biophys. Acta. 1465: 199-218.

BECKER, D., GEIGER, D., DUNKEL, M., ROLLER, A., BERTL, A., LATZ, A., CARPANETO, A., DIETRICH, P., ROELFSEMA, M.R., VOELKER, C., SCHMIDT, D., MUELLER-ROEBER, B., CZEMPINSKI, K., and HEDRICH, R. (2004). AtTPK4, an Arabidopsis tandem-pore $\mathrm{K}^{+}$channel, poised to control the pollen membrane voltage in a pH- and $\mathrm{Ca}^{2+}$-dependent manner. Proc. Natl. Acad. Sci. USA 101: 15621-15626.

BECKER, J.D., BOAVIDA, L.C., CARNEIRO, J., HAURY, M., and FEIJÓ, J.A. (2003). Transcriptional profiling of Arabidopsis tissues reveals the unique characteristics of the pollen transcriptome. Plant Physiol. 133: 713-725.

BECKER, JD and FEIJÓ, JA (2007) How many genes are needed to make a pollen grain? Lessons from transcriptomics. Annals of Botany (Botanical Briefings); 100: 1117-1123.

BENKERT, R., OBERMEYER, G., and BENTRUP, F.W. (1997). The turgor pressure of growing lily pollen tubes. Protoplasma 198: 1-8.

BOAVIDA, L.C., BECKER, J.D., and FEIJÓ, J.A. (2005a). The making of gametes in higher plants. Int. J. Dev. Biol. 49: 595-614.

BOAVIDA, L.C., VIEIRA, A.M., BECKER, J.D., and FEIJÓ, J.A. (2005b). Gametophyte interaction and sexual reproduction: how plants make a zygote. Int. J. Dev. Biol. 49: 615-632.

BOCK, K.W., HONYS, D., WARD, J.M., PADMANABAN, S., NAWROCKI, E.P., HIRSCHI, K.D., TWELL, D., and SZE, H. (2006). Integrating membrane transport with male gametophyte development and function through transcriptomics.
Plant Physiol. 140: 1151-1168.

BUCH-PEDERSEN, M.J., RUDASHEVSKAYA, E.L., BERNER, T.S., VENEMA, K., and PALMGREN, M.G. (2006). Potassium as an intrinsic uncoupler of the plasma membrane $\mathrm{H}^{+}$-ATPase. J. Biol. Chem. 281: 38285-92

CARDENAS, L., LOVY-WHEELER, A., WILSEN, K.L., and HEPLER, P.K. (2005). Actin polymerization promotes the reversal of streaming in the apex of pollen tubes. Cell Motil. Cytoskeleton 61: 112-127.

CARDENAS, L., HOLDAWAY-CLARKE, T.L., SANCHEZ, F., QUINTO, C., FEIJÓ, J.A., KUNKEL, J.G., and HEPLER, P.K. (2000). lon changes in legume root hairs responding to Nod factors. Plant Physiol. 123: 443-452.

CARDENAS, L., MCKENNA, S.T., KUNKEL, J.G., and HEPLER, P.K. (2006). $\mathrm{NAD}(\mathrm{P}) \mathrm{H}$ Oscillates in Pollen Tubes and Is Correlated with Tip-Growth. Plant Physiol. 142: 1460-1468.

CAROL, R.J., and DOLAN, L. (2002). Building a hair: tip growth in Arabidopsis thaliana root hairs Phil. Trans. R. Soc. Lond. 357: 815-821.

CELLIER, F., CONEJERO, G., RICAUD, L., LUU, D.T., LEPETIT, M., GOSTI, F. and CASSE, F. (2004). Characterization of AtCHX17, a member of the cation/ $\mathrm{H}^{+}$exchangers, $\mathrm{CHX}$ family, from Arabidopsis thaliana suggests a role in $\mathrm{K}^{+}$ homeostasis. Plant J. 39: 834-846.

CERTAL, A.C., ALMEIDA, R.B., CARVALHO, L.M., WONG, E., MORENO, N., MICHARD, E., CARNEIRO, J., RODRIGUÉZ-LÉON, J., WU, H.M., CHEUNG, A.Y., and FEIJÓ, J.A. (2008) Exclusion of a Proton ATPase from the Apical Membrane Is Associated with Cell Polarity and Tip Growth in Nicotiana tabacum Pollen Tubes. Plant Cell. tpc.106.047423v1

DAVENPORT, R. (2002). Glutamate receptors in plants. Ann. Bot. (Lond)90: 549557.

DEMIDCHIK, V., and MAATHUIS, F.J. (2007). Physiological roles of nonselective cation channels in plants: from salt stress to signalling and development. New. Phytol. 17: 387-404.

DESBROSSES, G., JOSEFSSON, C., RIGAS, S., HATZOPOULOS, P., and DOLAN, L. (2003). AKT1 and TRH1 are required during root hair elongation in Arabidopsis. J. Exp. Bot. 54: 781-788

DUTTA, R., and ROBINSON, K.R. (2004). Identification and characterization of stretch-activated ion channels in pollen protoplasts. Plant Physiol. 135: 13981406.

EPSTEIN, E. (1976). Kinetics of ion transport and the carrier concept. In Transport in Plants, Vol. 2, U. Luttge and M.G. Pitman, eds (Heidelberg, Germany: Springer-Verlag), pp. 70-94.

FAN, L.M., WU, W.H., and YANG, H.Y. (1999). Identification and characterization of the inward $\mathrm{K}^{+}$channel in the plasma membrane of Brassica pollen protoplasts. Plant Cell Physiol. 40: 859-865.

FAN, L.M., WANG, Y.F., and WU, W.H. (2003). Outward $\mathrm{K}^{+}$channels in Brassica chinensis pollen protoplasts are regulated by external and internal $\mathrm{pH}$. Protoplasma 220: 143-152.

FAN, L.M., WANG, Y.F., WANG, H., and WU, W.H. (2001). In vitro Arabidopsis pollen germination and characterization of the inward potassium currents in Arabidopsis pollen grain protoplasts. J. Exp. Bot. 52: 1603-1614

FEIJÓ, J.A. (1995) A contribution to the study of sexual plant reproduction in Ophrys lutea. PhD. Thesis, ed. Univ. Lisboa, Lisboa.

FEIJÓ, J.A. (1999) The pollen tube oscillator: towards the molecular mechanism of tip growth?. In M.Cresti, G.Cai and S.Moscatelli (eds.) "Fertilization in Higher Plants: Molecular and Cytological Aspects". Springer-Verlag. Heidelberg, Berlin. pp.317-336

FEIJÓ, J.A., MALHÓ, R., and OBERMEYER, G. (1995). Ion dynamics and its possible role during in vitro pollen germination and tube growth. Protoplasma 187: 155-167.

FEIJÓ, J.A., SAINHAS, J., HACKETT, G.R., KUNKEL, J.G., and HEPLER, P.K. (1999). Growing pollen tubes possess a constitutive alkaline band in the clear zone and a growth-dependent acidic tip. J. Cell. Biol. 144: 483-496.

FEIJÓ, J.A., COSTA, S.S., PRADO, A.M., BECKER, J.D., and CERTAL, A.C. (2004). Signalling by tips. Curr. Opin. Plant Biol. 7: 589-598.

FEIJÓ, J.A., SAINHAS, J., HOLDAWAY-CLARKE, T., CORDEIRO, M.S., KUNKEL, J.G., and HEPLER, P.K. (2001). Cellular oscillations and the regulation of growth: the pollen tube paradigm. Bioessays 23: 86-94.

FEIJÓ, J.A., MALHÓ, R. and PAIS, M.S. (1992). A cytochemical study on the role of ATPases during pollen germination in Agapanthus umbelatus. Sex. Plant 
Reprod. 5: 138-145.

FRICKER, M.D., WHITE, N.S., and OBERMEYER, G. (1997). pH gradients are not associated with tip growth in pollen tubes of Lilium longiflorum. J. Cell. Sci. 110 (Pt 15): 1729-1740.

FRIETSCH, S., WANG, Y.F., SLADEK, C., POULSEN, L.R., ROMANOWSKY, S.M., SCHROEDER, J.I., and HARPER, J.F. (2007) A cyclic nucleotide-gated channel is essential for polarized tip growth of pollen. Proc. Natt. Acad. Sci. USA $104: 14531-6$

GASSMANN, W., and SCHROEDER, J.I. (1994). Inward-Rectifying $\mathrm{K}^{+}$Channels in Root Hairs of Wheat (A Mechanism for Aluminum-Sensitive Low-Affinity K+ Uptake and Membrane Potential Control). Plant Physiol. 105: 1399-1408.

GAYMARD, F., PILOT, G., LACOMBE, B., BOUCHEZ, D., BRUNEAU, D., BOUCHEREZ, J., MICHAUX-FERRIERE, N., THIBAUD, J.B., and SENTENAC, H. (1998). Identification and disruption of a plant shaker-like outward channel involved in $\mathrm{K}^{+}$release into the xylem sap. Ce//94: 647-655.

GEHWOLF, R., GRIESSNER, M., PERTL, H., and OBERMEYER, G. (2002). First patch, then catch: measuring the activity and the mRNA transcripts of a proton pump in individual Lilium pollen protoplasts. FEBS Lett. 512: 152-156.

GEITMANN, A., and CRESTI, M. (1998). $\mathrm{Ca}^{2+}$ channels control the rapid expansions in pulsating growth of Petunia hybrida pollen tubes. Plant Physiol. 152: 439-447.

GILROY, S., and JONES, D.L. (2000). Through form to function: root hair development and nutrient uptake. Trends Plant Sci. 5: 56-60.

GRADMANN, D., BLATT, M.R., and THIEL, G. (1993). Electrocoupling of ion transporters in plants. J. Membr. Biol. 136: 327-332.

GRIESSNER, M., and OBERMEYER, G. (2003). Characterization of whole-cell K+ currents across the plasma membrane of pollen grain and tube protoplasts of Lilium longiflorum. J. Membr. Biol. 193: 99-108.

GU, Y., FU, Y., DOWD, P., LI, S., VERNOUD, V., GILROY, S., and YANG, Z. (2005). A Rho family GTPase controls actin dynamics and tip growth via two counteracting downstream pathways in pollen tubes. J. Cell. Biol. 169: 127-138.

HELLING, D., POSSART, A., COTTIER, S., KLAHRE, U., and KOST, B. (2006). Pollen Tube Tip Growth Depends on Plasma Membrane Polarization Mediated by Tobacco PLC3 Activity and Endocytic Membrane Recycling. Plant Cel/18: 3519-3534.

HETHERINGTON, A.M., and BROWNLEE, C. (2004). The generation of $\mathrm{Ca}^{2+}$ signals in plants. Annu. Rev. Plant Biol. 55: 401-427.

HOLDAWAY-CLARKE, T.L., FEIJÓ, J.A., HACKETT, G.R., KUNKEL, J.G., and HEPLER, P.K. (1997). Pollen Tube Growth and the Intracellular Cytosolic Calcium Gradient Oscillate in Phase while Extracellular Calcium Influx Is Delayed. Plant Cel/9: 1999-2010.

HOLDAWAY-CLARKE, T.L., WEDDLE, N.M., KIM, S., ROBI, A., PARRIS, C., KUNKEL, J.G., and HEPLER, P.K. (2003). Effect of extracellular calcium, pH and borate on growth oscillations in Lilium formosanum pollen tubes. J. Exp. Bot. 54: 65-72.

HONYS, D., and TWELL, D. (2003). Comparative analysis of the Arabidopsispollen transcriptome. Plant Physiol. 132: 640-652.

HONYS, D., and TWELL, D. (2004). Transcriptome analysis of haploid male gametophyte development in Arabidopsis. Genome Biol. 5: R85.

HWANG, J.U., GU, Y., LEE, Y.J., and YANG, Z. (2005). Oscillatory ROP GTPase activation leads the oscillatory polarized growth of pollen tubes. Mol. Biol. Cell. 16: 5385-5399

IWANO, M., SHIBA, H., MIWA, T., CHE, F.S., TAKAYAMA, S., NAGAI, T., MIYAWAKI, A., and ISOGAI, A. (2004). $\mathrm{Ca}^{2+}$ dynamics in a pollen grain and papilla cell during pollination of Arabidopsis. Plant Physiol. 136: 3562-3571.

JAFFE, L.A., WEISENSEEL, M.H., and JAFFE, L.F. (1975). Calcium accumulations within the growing tips of pollen tubes. J. Cell. Biol. 67: 488-492.

JOHANSSON, I., WULFETANGE, K., POREE, F., MICHARD, E., GAJDANOWICZ, P., LACOMBE, B., SENTENAC, H., THIBAUD, J.B., MUELLER-ROEBER, B. BLATT, M.R., and DREYER, I. (2006). External $\mathrm{K}^{+}$modulates the activity of the Arabidopsis potassium channel SKOR via an unusual mechanism. Plant J. 46: 269-281.

KUEHTREIBER, W., and JAFFE, L.F. (1990). Detection of extracellular calcium gradients with a calcium-specific vibrating electrode. J. Cell. Biol. 110: 15651573.
KUNKEL, J.G., L.-Y. LINX, Y. XU, A. M. M. PRADO, J. A. FEIJÓ, P. P. HWANGX and P. K. HEPLER. (2001) The strategic use of Good buffers to measure proton gradients about growing pollen tubes. In Geitmann, A. et al. (eds.) Cell Biology of Fungal and Tip Growth. NATO Science Series I:Life and Behavioural Sci., Vol.328, IOS Press, Amsterdam, Netherlands, pp.81-94

KUNKEL, J.G., CORDEIRO, S., XU, J., SHIPLEY, A.M. and FEIJÓ, J.A. (2006) The use of non-invasive ion-selective microelectrode techniques for the study of plant development. In Volkov, V. (ed.) Plant Electrophysiology - Theory and Methods, Springer-Verlag, Berlin, Heidelberg, pp. 109-137.

LACOMBE, B., PILOT, G., GAYMARD, F., SENTENAC, H., and THIBAUD, J.B. (2000). $\mathrm{pH}$ control of the plant outwardly-rectifying potassium channel SKOR. FEBS Lett. 466: 351-354.

LEFEBVRE, B., ARANGO, M., OUfATtOLE, M., CROUZET, J., PURNELLE, B. and BOUTRY, M. (2005). Identification of a Nicotiana plumbaginifolia plasma membrane $\mathrm{H}^{+}$-ATPase gene expressed in the pollen tube. Plant Mol. Biol. 58 : 775-787.

LI, L., KIM, B.G., CHEONG, Y.H., PANDEY, G.K., and LUAN, S. (2006). A Ca ${ }^{2+}$ signaling pathway regulates a $\mathrm{K}^{+}$channel for low-K response in Arabidopsis. Proc. Natl. Acad. Sci. USA 103: 12625-12630.

LIU, K., LI, L., and LUAN, S. (2006). Intracellular K+ sensing of SKOR, a Shaker-type $\mathrm{K}^{+}$channel from Arabidopsis. Plant J. 46: 260-268.

LOVY-WHEELER, A., KUNKEL, J.G., ALLWOOD, E.G., HUSSEY, P.J., and HEPLER, P.K. (2006). Oscillatory increases in alkalinity anticipate growth and may regulate actin dynamics in pollen tubes of lily. Plant Cel/18: 2182-2193.

LUO, H., MORSOMME, P., and BOUTRY, M. (1999). The two major types of plant plasma membrane $\mathrm{H}^{+}$-ATPases show different enzymatic properties and confe differential pH sensitivity of yeast growth. Plant Physiol. 119: 627-634.

MALHÓ, R., READ, N.D., PAIS, M. and TREWAVAS, A.J. (1994) Role of cytosolic calcium in the reorientation of pollen tube growth. Plant J. 5: 331-341.

MALHÓ, R., and TREWAVAS, A.J. (1996). Localized Apical Increases of Cytosolic Free Calcium Control Pollen Tube Orientation. Plant Cel/8: 1935-1949.

MALHÓ, R., READ, N.D., TREWAVAS, A.J., and PAIS, M.S. (1995). Calcium Channel Activity during Pollen Tube Growth and Reorientation. Plant Cel/7: 1173-1184.

MALHÓ, R., LIU, Q., MONTEIRO, D., RATO, C., CAMACHO, L., and DINIS, A (2006). Signalling pathways in pollen germination and tube growth. Protoplasma 228: 21-30.

MASCARENHAS, J.P. (1993) Molecular mechanisms of pollen tube growth and differentiation. Plant Ce//5: 1303-14.

MESSERLI, M.A., and ROBINSON, K.R. (1997). Tip localized $\mathrm{Ca}^{2+}$ pulses are coincident with peak pulsatile growth rates in pollen tubes of Lilium longiflorum. J. Cell. Sci. 110 (Pt 11): 1269-1278.

MESSERLI, M.A., and ROBINSON, K.R. (2003). Ionic and osmotic disruptions of the lily pollen tube oscillator: testing proposed models. Planta 217: 147-157.

MESSERLI, M.A., DANUSER, G., and ROBINSON, K.R. (1999). Pulsatile influxes of $\mathrm{H}^{+}, \mathrm{K}^{+}$and $\mathrm{Ca}^{2+}$ lag growth pulses of Lilium longiflorum pollen tubes. J. Cell. SCi. 112 (Pt 10): 1497-1509.

MESSERLI, M.A., CRETON, R., JAFFE, L.F., and ROBINSON, K.R. (2000). Periodic increases in elongation rate precede increases in cytosolic $\mathrm{Ca}^{2+}$ during pollen tube growth. Dev. Biol. 222: 84-98.

MESSERLI, M.A., SMITH, P.J., LEWIS, R.C., and ROBINSON, K.R. (2004) Chloride fluxes in lily pollen tubes: a critical reevaluation. Plant J. 40: 799-812.

MICHARD, E., DIAS, P., and FEIJÓ J.A. (2008) Tobacco pollen tubes as cellular models for ion dynamics: improved spatial and temporal resolution of extracellular flux and free cytosolic concentration of calcium and protons using pHluorin and YC3.1 CaMeleon. Sex. Plant Reprod. DOI 10.1007/s00497-008-0076-x

MIESENBOCK, G., DE ANGELIS, D.A. and ROTHMAN,J.E. (1998) Visualizing secretion and synaptic transmission with $\mathrm{pH}$-sensitive green fluorescent proteins. Nature, 394: 192-195.

MIYAWAKI, A., GRIESBECK, O., HEIM, R. and TSIEN, R.Y. (1999) Dynamic and quantitative $\mathrm{Ca}^{2+}$ measurements using improved cameleons. Proc. Natl. Acad. Sci. USA 96: 2135-2140.

MILLER, D.D., CALLAHAM, D.A., GROSS, D.J., and HEPLER, P.K. (1992). Free $\mathrm{Ca}^{2+}$ in growing pollen tubes of Lillium J. Cell. Sci. 101: 7-12.

MORENO, N., COLAÇO, R. and FEIJÓ, J.A. (2007) The pollen tube oscillator: 
integrating biophysics and biochemistry into cellular growth and morphogenesis. InMancuso, S, and Shabala, S (eds.) Rhythms in Plants: Phenomenology, Mechanisms, and Adaptive Significance, Springer-Verlag, Heidelberg, pp. 3962

MOULINE, K., VERY, A.A., GAYMARD, F., BOUCHEREZ, J., PILOT, G., DEVIC, M., BOUCHEZ, D., THIBAUD, J.B., and SENTENAC, H. (2002). Pollen tube development and competitive ability are impaired by disruption of a Shaker $\mathrm{K}{ }^{+}$channel in Arabidopsis. Genes Dev. 16: 339-350.

NEGI, J., MATSUDA, O., NAGASAWA, T., OBA, Y., TAKAHASHI, H., KAWAIYAMADA, M., UCHIMIYA, H., HASHIMOTO, M., and IBA, K. (2008) CO2 regulator SLAC1 and its homologues are essential for anion homeostasis in plant cells. Nature 452: 483-6.

NOIR, S., BRAUTIGAM, A., COLBY, T., SCHMIDT, J., and PANSTRUGA, R. (2005). A reference map of the Arabidopsis thaliana mature pollen proteome. Biochem. Biophys. Res. Com. 337: 1257-1266.

OBERMAYER, G., and BLATT, M.R. (1995). Electrical properties of intact pollen grains of Lilium longiflorum: characteristics of the non-germinating pollen grain. J. Exp. Bot. 46: 803-813.

OBERMEYER, G., LÜTZELSCHWAB, M., HEUMANN, H.-G. and WEISENSEEL, M. H. (1992). Immunolocalization of $\mathrm{H}^{+}-A T P a s e s$ in the plasma membrane of pollen grains and pollen tubes of Lilium longiflorum. Protoplasma 171: 55-63.

OBERMEYER, G., and WEISENSEEL, M.H. (1991). Calcium channel blocker and calmodulin antagonists affect the gradient of free calcium ions in lily pollen tubes. Eur. J. Cell. Biol. 56: 319-327.

PALANIVELU, R., and PREUSS, D. (2000). Pollen tube targeting and axon guidance: parallels in tip growth mechanisms. Trends Cell Biol. 10: 517-524.

PALMGREN, M.G. (2001). Plant membrane $\mathrm{H}^{+}-$ATPases: powerhouses for Nutrient Uptake. Annu. Rev. Plant Physiol. Plant Mol. Biol. 52: 817-845.

PALMGREN, M.G., and CHRISTENSEN, G. (1994). Functional comparisons between plant plasma membrane $\mathrm{H}^{+}-\mathrm{ATPase}$ isoforms expressed in yeast. $\mathrm{J}$. Biol. Chem. 269: 3027-3033.

PARTON, R.M., FISCHER-PARTON, S., WATAHIKI, M.K., and TREWAVAS, A.J. (2001). Dynamics of the apical vesicle accumulation and the rate of growth are related in individual pollen tubes. J. Cell. Sci. 114: 2685-2695.

PARTON, R.M., FISCHER-PARTON, S., TREWAVAS, A.J., and WATAHIKI, M.K. (2003). Pollen tubes exhibit regular periodic membrane trafficking events in the absence of apical extension. J. Cell. Sci. 116: 2707-2719.

PERTL, H., HIMLY, M., GEHWOLF, R., KRIECHBAUMER, R., STRASSER, D., MICHALKE, W., RICHTER, K., FERREIRA, F., and OBERMEYER, G. (2001). Molecular and physiological characterisation of a 14-3-3 protein from lily pollen grains regulating the activity of the plasma membrane $\mathrm{H}^{+}-\mathrm{ATP}$ ase during pollen grain germination and tube growth. Planta 213: 132-141.

PIERSON, E.S., MILLER, D.D., CALLAHAM, D.A., VAN AKEN, J., HACKETT, G., and HEPLER, P.K. (1996). Tip-localized calcium entry fluctuates during pollen tube growth. Dev. Biol. 174: 160-173.

PIERSON, E.S., MILLER, D.D., CALLAHAM, D.A., SHIPLEY, A.M., RIVERS, B.A., CRESTI, M., and HEPLER, P.K. (1994). Pollen tube growth is coupled to the extracellular calcium ion flux and the intracellular calcium gradient: effect of BAPTA-type buffers and hypertonic media. Plant Ce//6: 1815-1828.

PINA, C., PINTO, F., FEIJÓ, J.A., and BECKER, J.D. (2005). Gene family analysis of the Arabidopsis pollen transcriptome reveals biological implications for cell growth, division control, and gene expression regulation. Plant Physiol. 138: 744-756.

QU, H.Y., SHANG, Z.L., ZHANG, S.L., LIU, L.M., and WU, J.Y. (2007) Identification of hyperpolarization-activated calcium channels in apical pollen tubes of Pyrus pyrifolia. New Phytol. 174: 524-36

RATHORE, K.S., CORK, R.J., and ROBINSON, K.R. (1991). A cytoplasmic gradient of $\mathrm{Ca}^{2+}$ is correlated with the growth of lily pollen tubes. Dev. Biol. 148: 612-619.

RATO, C., MONTEIRO, D., HEPLER, P.K., and MALHÓ, R. (2004). Calmodulin activity and CAMP signalling modulate growth and apical secretion in pollen tubes. Plant J. 38: 887-897.

REISS, H.D., and HERTH, W. (1978). Visualization of $\mathrm{Ca}^{2+}$-gradients in growing pollen tubes of Lillium longituflorum with Chlorotetracycline fluorescence Protoplasma 97: 373-377.

REISS, H.D., and HERTH, W. (1979). Calcium Gradients in tip growing plant cells visualized by Chlororetracycline fluorescence. Planta 146: 615-621.

REISS, H.D., and HERTH, W. (1985). Nifedipine-sensitive calcium channels are involved in polar growth of lily pollen tubes. J. Cell. Sci. 76: 247-254.

RIGAS, S., DEBROSSES, G., HARALAMPIDIS, K., VICENTE-AGULLO, F., FELDMANN, K.A., GRABOV, A., DOLAN, L., and HATZOPOULOS, P. (2001) TRH1 encodes a potassium transporter required for tip growth in Arabidopsis root hairs. Plant Cel/13: 139-151.

ROBERTSON, W.R., CLARK, K., YOUNG, J.C., and SUSSMAN, M.R. (2004). An Arabidopsis thaliana plasma membrane proton pump is essential for pollen development. Genetics 168: 1677-1687.

ROBINSON, K.R., and MESSERLI, M.A. (2002). Pulsating ion fluxes and growth at the pollen tube tip. SCi. STKEPE51.

RODRIGUEZ-ROSALES, M.P., ROLDÁN, M., BELVER, A., and DONAIRE, J.P. (1989). Correlation between in vitrogermination capacity and proton extrusion in olive pollen. Plant Physiol. Biochem. 27: 723-728.

ROELFSEMA, M.R., and HEDRICH, R. (2005). In the light of stomatal opening: new insights into 'the Watergate'. New Phytol. 167: 665-691.

ROY, J.S., HOLDAWAY-CLARKE, T., HACKETT, G., KUNKEL, J.G., LORD, E.M., and HEPLER, P.K. (1999). Uncoupling secretion and tip growth in lily pollen tubes: evidence for the role of calcium in exocytosis. Plant J. 19: 379-386.

SCHIOTT, M., ROMANOWSKY, S.M., BAEKGAARD, L., JAKOBSEN, M.K., PALMGREN, M.G., and HARPER, J.F. (2004). A plant plasma membrane $\mathrm{Ca}^{2+}$ pump is required for normal pollen tube growth and fertilization. Proc. Natt. Acad. Sci. USA 101: 9502-9507.

SHANG, Z.L., MA, L.G., ZHANG, H.L., HE, R.R., WANG, X.C., CUI, S.J., and SUN, D.Y. (2005) $\mathrm{Ca}^{2+}$ influx into lily pollen grains through a hyperpolarizationactivated $\mathrm{Ca}^{2+}$-permeable channel which can be regulated by extracellular $\mathrm{CaM}$ Plant Cell Physiol. 46: 598-608.

SONDERGAARD, T.E., SCHULZ, A., and PALMGREN, M.G. (2004). Energization of transport processes in plants. roles of the plasma membrane $\mathrm{H}^{+}$-ATPase. Plant Physiol. 136: 2475-2482.

SUH, S.J., WANG, Y.F., FRELET, A., LEONHARDT, N., KLEIN, M., FORESTIER C., MUELLER-ROEBER, B., CHO, M., MARTINOIA, E., and SCHROEDER, J. (2007). The ATP binding cassette transporter AtMRP5 modulates anion and $\mathrm{Ca}^{2+}$ channel activities in Arabidopsis guard cells. J. Biol. Chem. 282:19161924.

SZE, H., PADMANABAN, S., CELLIER, F., HONYS, D., CHENG, N.H., BOCK, K.W., CONEJERO, G., LI, X., TWELL, D., WARD, J.M., and HIRSCHI, K.D. (2004). Expression patterns of a novel AtCHX gene family highlight potential roles in osmotic adjustment and $\mathrm{K}^{+}$homeostasis in pollen development. Plant Physiol. 136: 2532-2547.

TALKE, I.N., BLAUDEZ, D., MAATHUIS, F.J., and SANDERS, D. (2003). CNGCs: prime targets of plant cyclic nucleotide signalling? Trends Plant Sci. 8: 286-293.

THIEL, G., MACROBBIE, E.A., and BLATT, M.R. (1992). Membrane transport in stomatal guard cells: the importance of voltage control. J. Membr. Biol. 126: 1 18.

VAHISALU, T., KOLLIST, H., WANG, Y.F., NISHIMURA, N., CHAN, W.Y., VALERIO, G., LAMMINMÄKI, A., BROSCHÉ, M., MOLDAU, H., DESIKAN, R., SCHROEDER, J.I., and KANGASJÄRVI, J. (2008) SLAC1 is required for plant guard cell S-type anion channel function in stomatal signalling. Nature. 452 487-91.

VERY, A.A., and DAVIES, J.M. (2000). Hyperpolarization-activated calcium channels at the tip of Arabidopsis root hairs. Proc. Natl. Acad. Sci. USA 97: 9801 9806.

WATAHIKI, M.K., TREWAVAS, A.J. and PARTON, R.M. (2004) Fluctuations in the pollen tube tip-focused calcium gradient are not reflected in nuclear calcium level: a comparative analysis using recombinant yellow cameleon calcium reporter. J. Sex. Plant Reprod. 17: 125-130.

WANG, Y.F., FAN, L.M., ZHANG, W.Z., ZHANG, W., and WU, W.H. (2004). $\mathrm{Ca}^{2+}$ permeable channels in the plasma membrane of Arabidopsis pollen are regulated by actin microfilaments. Plant Physiol. 136: 3892-3904.

WEISENSEEL, M.H., and JAFFE, L.F. (1976). The major growth current through lily pollen tubes enters as $\mathrm{K}^{+}$and leaves as $\mathrm{H}^{+}$. Planta 133: 1-7.

WEISENSEEL, M.H., and WENISCH, H. (1980). The membrane potential of Growing lily pollen. Z. Pflanzenphysiol. 99: 313-323. 
WEISENSEEL, M.H., NUCCITELLI, R., and JAFFE, L.F. (1975). Large electrical currents traverse growing pollen tubes. J. Cell. Biol. 66: 556-567.

WU, Y., XU, X., LI, S., LIU, T., MA, L., and SHANG, Z. (2007) Heterotrimeric Gprotein participation in Arabidopsis pollen germination through modulation of a plasma membrane hyperpolarization-activated $\mathrm{Ca}^{2+}$-permeable channel. New Phytol. 176: 550-9.

YOON, G.M., DOWD, P.E., GILROY, S., and MCCUBBIN, A.G. (2006). Calciumdependent protein kinase isoforms in Petunia have distinct functions in pollen tube growth, including regulating polarity. Plant Cel/18: 867-878.
ZHAO, R., DIELEN, V., KINET, J.M., and BOUTRY, M. (2000). Cosuppression of a plasma membrane $\mathrm{H}^{+}$-ATPase isoform impairs sucrose translocation, stomatal opening, plant growth, and male fertility. Plant Ce//12: 535-546.

ZONIA, L., CORDEIRO, S. and FEIJÓ, J.A. (2001) Ion dynamics and the control of hydrodynamics in the regulation of pollen tube growth. J. Sex. Plant Reprod. 14: 111-116

ZONIA, L., CORDEIRO, S., TUPY, J., and FEIJÓ, J.A. (2002). Oscillatory chloride efflux at the pollen tube apex has a role in growth and cell volume regulation and is targeted by inositol 3,4,5,6-tetrakisphosphate. Plant Ce//14: 2233-2249.

\section{Related, previously published Int. J. Dev. Biol. articles}

See our recent Special Issue Ear Development edited by Fernando Giraldez and Bernd Fritzsch at: http://www.ijdb.ehu.es/web/contents.php?vol=51\&issue=6-7

Molecular evolution of the vertebrate mechanosensory cell and ear Bernd Fritzsch, Kirk W. Beisel, Sarah Pauley and Garrett Soukup Int. J. Dev. Biol. (2007) 51: 663-678

Shaping the mammalian auditory sensory organ by the planar cell polarity pathway Michael Kelly and Ping Chen

Int. J. Dev. Biol. (2007) 51: 535-547

Biophysical regulation during cardiac development and application to tissue engineering Sharon Gerecht-Nir, Milica Radisic, Hyoungshin Park, Christopher Cannizzaro, Jan Boublik, Robert Langer and Gordana Vunjak-Novakovic Int. J. Dev. Biol. (2006) 50: 233-243

Gametophyte interaction and sexual reproduction: how plants make a zygote Leonor C. Boavida, Ana Maria Vieira, Jörg D. Becker and José A. Feijó Int. J. Dev. Biol. (2005) 49: 615-632

The making of gametes in higher plants Leonor C. Boavida, Jörg D. Becker and José A. Feijó Int. J. Dev. Biol. (2005) 49: 595-614

The choice between epidermal and neural fate: a matter of calcium Marc Moreau and Catherine Leclerc Int. J. Dev. Biol. (2004) 48: 75-84

The early microspore embryogenesis pathway in barley is accompanied by concrete ultrastructural and expression changes

C Ramirez, PS Testillano, AM Castillo, MP Valles, MJ Coronado, L Cistue, MD Risueno Int. J. Dev. Biol. (2001) 45: S57-S58

Early stages of pollen embryogenesis in barley anther cultures induced by pretreatment with mannitol

A Pulido, A Castillo, MP Valles, A Olmedilla

Int. J. Dev. Biol. (2001) 45: S55-S56

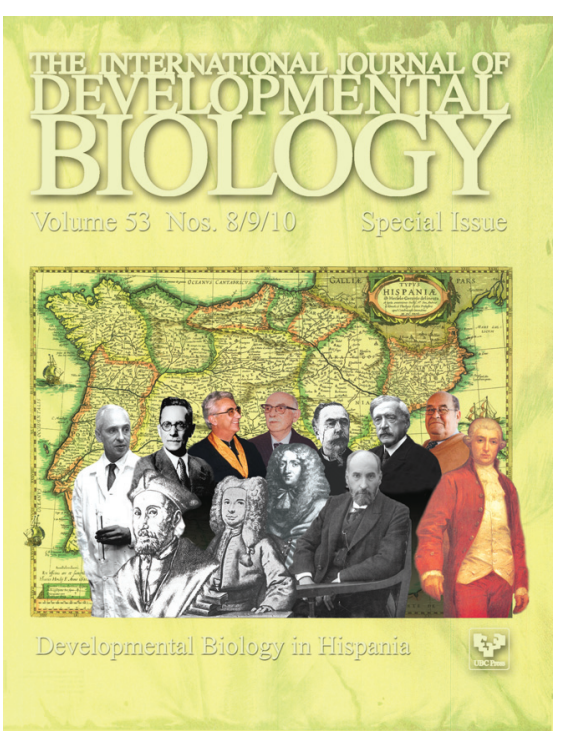

5 yr ISI Impact Factor $(2008)=3.271$

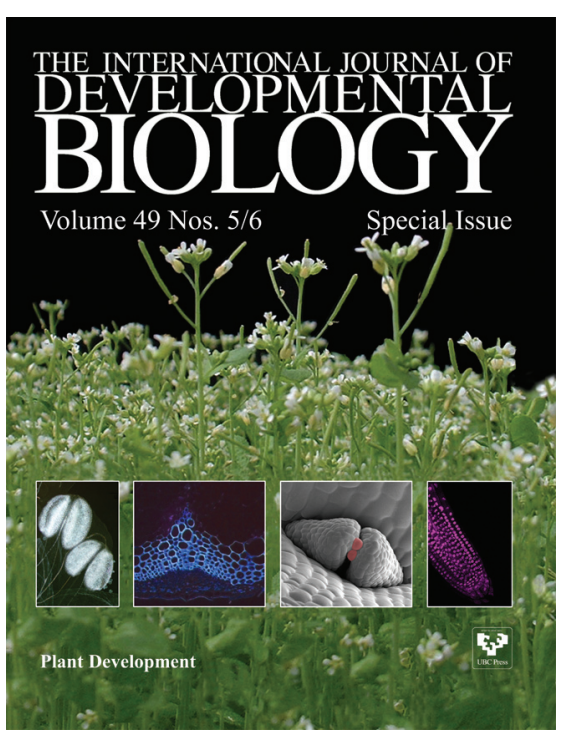

